STATUS OF GROUND-WATER RESOURCES AT U.S. NAVY SUPPORT FACILITY, DIEGO GARCIA: SUMMARY OF HYDROLOGIC AND CLIMATIC DATA, JANUARY 1993 THROUGH SEPTEMBER 1995 by Jill D. Torikai

U.S. GEOLOGICAL SURVEY

Open-File Report 96-165

Prepared in cooperation with the U.S. DEPARTMENT OF THE NAVY NAVY SUPPORT FACILITY, DIEGO GARCIA

Honolulu, Hawaii 1996 


\section{U.S. DEPARTMENT OF THE INTERIOR \\ BRUCE BABBITT, Secretary}

\section{U.S. GEOLOGICAL SURVEY}

Gordon P. Eaton, Director

Any use of trade, product, or firm names in this publication is for descriptive purposes only and does not imply endorsement by the U.S. Government.

For sale by the U.S. Geological Survey

Earth Science Information Center

Open-File Reports Section

Box 25286, MS 517

Denver Federal Center

Denver, CO 80225

For additional information write to:

District Chief

U.S. Geological Survey

677 Ala Moana Blvd., Suite 415

Honolulu, HI 96813 


\section{CONTENTS}

Executive Summary

Introduction

Background

Organization of Report

Rainfall

Ground-Water Withdrawal

Chloride Concentration of Pumped Ground Water

Chloride Concentration of Ground Water in Monitoring Wells

Fuel-Diversion Program at Air Operations.

Hydrologic-Data Section A. Maps of Production and Monitoring Wells at Cantonment and Air Operations

Hydrologic-Data Section B. Graphs of Monthly Mean Ground-Water Withdrawal, January 1993 through September 1995.

Hydrologic-Data Section C. Graphs of Chloride Concentration of Pumped

Water, January 1993 through September 1995

References Cited 


\section{FIGURES}

1. Map showing areas of ground-water production, Diego Garcia.............................. 3

2. Graphs of monthly rainfall and monthly departure from mean monthly rainfall at Air Operations, Diego Garcia, January 1993 through September 1995

3. Graphs of monthly mean ground-water withdrawal islandwide and in the ground-water production areas, Diego Garcia, January 1993 through September 1995

4. Graphs of chloride concentration of pumped water (sampled at weekly intervals) in the ground-water production areas, Diego Garcia, January 1993 through September 1995

5. Graphs of chloride concentration of ground water (sampled at monthly intervals) in monitoring wells at site AW16 at Cantonment, Diego Garcia, January 1993 through September 1995

6. Graphs of chloride concentration of ground water (sampled at monthly intervals) in monitoring wells at site BW09 at Air Operations, Diego Garcia, January 1993 through September 1995

7. Graphs of monthly mean ground-water withdrawal and injection at wells AO-10 through AO-15 at Air Operations, Diego Garcia, January 1993 through September 1995

\section{TABLE}

1. Target and actual withdrawal and injection rates for hydraulic-diversion program 


\section{CONVERSION FACTORS AND ABBREVIATION}

\begin{tabular}{rll} 
Multiply & By & To obtain \\
foot (ft) & 0.3048 & meter \\
gallon (gal) & 3.785 & liter \\
gallon per day (gal/d) & 3.785 & liter per day \\
cubic meter per second \\
million gallons per day (Mgal/d) & 0.04381 & millimeter \\
inch (in.) & 25.4 & millimeter per year \\
inch per year (in/yr) & 25.4 & \\
\hline
\end{tabular}

Abbreviation used in water-quality descriptions $\mathrm{mg} / \mathrm{L}=$ milligrams per liter 


\section{STATUS OF GROUND-WATER RESOURCES AT \\ U.S. NAVY SUPPORT FACILITY, DIEGO GARCIA: \\ SUMMARY OF HYDROLOGIC AND CLIMATIC DATA, JANUARY 1993 THROUGH SEPTEMBER 1995}

\section{EXECUTIVE SUMMARY}

This report contains hydrologic and climatic data that describe the status of ground-water resources at U.S. Navy Support Facility, Diego Garcia. Data presented are from January 1993 through September 1995, although the report focuses on hydrologic events from July through September 1995.

1. RAINFALL--Cumulative rainfall for July through September 1995 was about 15 inches which is 32 percent less than the mean cumulative rainfall of about 22 inches for July through September. July and August are within the annual dry season, while September is the start of the annual wet season. Mean cumulative rainfall is calculated for the fixed base period 1951-90.

2. GROUND-WATER WITHDRAWAL--Ground-water withdrawal during July through September 1995 averaged 888,500 gallons per day. Withdrawal for the same 3 months in 1994 averaged 919,400 gallons per day. Patterns of withdrawal during the third quarter of 1995 did not change significantly since 1993 at all five ground-water production areas.

\section{CHLORIDE CONCENTRATION OF PUMPED GROUND WATER--At the end of} September 1995, the chloride concentration of the composite water supply was 51 milligrams per liter, well below the 250 milligrams per liter secondary drinking-water standard established by the U.S. Environmental Protection Agency. Chloride concentrations of the composite water supply from July through September 1995 ranged between 42 and 68 milligrams per liter.

\section{CHLORIDE CONCENTRATION OF GROUND WATER IN MONITORING WELLS--} Chloride concentration of ground water in monitoring wells at Cantonment and Air Operations continued to increase since April 1995, with water from the deepest monitoring wells increasing in chloride concentration by as much as 2,000 milligrams per liter.

\section{FUEL-DIVERSION PROGRAM AT AIR OPERATIONS--A fuel leak at Air Operations} caused the shutdown of ten wells in May 1991. Four of the wells resumed pumping for watersupply purposes in April 1992. The remaining six wells are being used to hydraulically divert fuel migration away from water-supply wells by recirculating about 150,000 gallons of water each day. 


\title{
STATUS OF GROUND-WATER RESOURCES AT \\ U.S. NAVY SUPPORT FACILITY, DIEGO GARCIA: SUMMARY OF HYDROLOGIC AND CLIMATIC DATA, JANUARY 1993 THROUGH SEPTEMBER 1995
}

\author{
By Jill D. Torikai \\ INTRODUCTION
}

\section{Background}

Diego Garcia Atoll is a British Indian Ocean Territory and the site of a U.S. Navy Support Facility. The island's drinking-water supply is derived from ground water by a system of more than 100 shallow wells in five production areas (fig. 1). Water from the Cantonment and Air Operations areas combined account for about 99 percent of total island pumpage. The remainder is pumped for local use at Industrial Site South, Transmitter Site, and GEODSS Site. The system has been in operation since 1978 and has provided about $1 \mathrm{Mgal} / \mathrm{d}$ since 1984 .

Long-term ground-water management has been facilitated by a cooperative agreement between the Navy Support Facility and the U.S. Geological Survey (USGS) since 1984. The Diego Garcia Long-Term Ground-Water Management Program involves data collection and analysis of daily rainfall, daily pumpage from individual wells, and chloride concentrations of water from all production and monitoring wells. The data are provided to the USGS by the Navy Support Facility, Public Works Department on Diego Garcia. The data are analyzed for hydrologic responses to pumping and climatic variability, and recent trends in the data are identified. This report is part of a series of quarterly data reports regarding Diego Garcia.

\section{Organization of Report}

This data summary contains hydrologic and climatic data that describe the status of ground-water resources at Navy Support Facility, Diego Garcia. Data presented are from January 1993 through September 1995. Data of primary relevance to the water supply are:

1. Rainfall

2. Volume of ground water withdrawn at production wells

3. Chloride concentration of pumped ground water

4. Chloride concentration of ground water sampled from monitoring wells

5. Volume of ground water injected at Air Operations

The following narrative highlights trends in the data for July through September 1995. Groundwater withdrawal and chloride concentrations of water from individual wells are presented in the "Hydrologic-Data Section." The data section contains the following:

A. Maps of production and monitoring wells at Cantonment and Air Operations

B. Graphs of monthly mean ground-water withdrawal, January 1993 through September 1995

C. Graphs of chloride concentration of pumped water, January 1993 through September 1995 


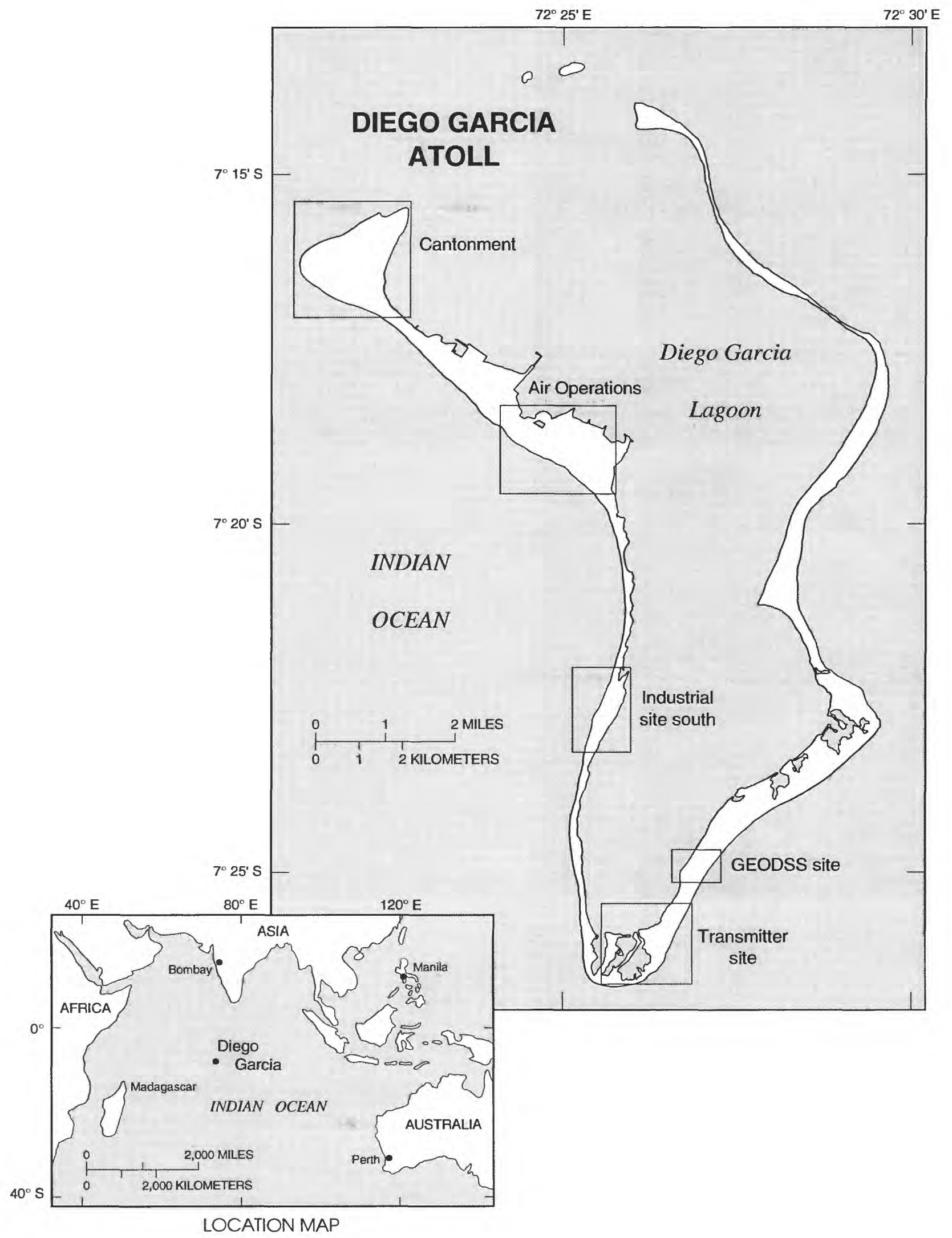

Figure 1. Areas of ground-water production, Diego Garcia. 


\section{RAINFALL}

Background.--Rainfall data are available since 1951, and all mean rainfall values in this report are calculated for the fixed base period 1951-90. The mean annual rainfall at Diego Garcia is $105.78 \mathrm{in} / \mathrm{yr}$. Rainfall varies considerably from month to month and from year to year. A wet season occurs from about September through February, and a dry season occurs from about March through August.

Recent trends.--Cumulative rainfall for July through September 1995 was 15.13 inches which is 32 percent less than the mean cumulative rainfall of 22.23 inches for July through September. For the same 3 months in 1993 and 1994, the cumulative rainfall was 12.65 inches and 25.93 inches, respectively. In 1993, the total rainfall of 94.77 inches was 10 percent below the mean annual rainfall, while in 1994 the total rainfall of 131.17 inches was 24 percent above the mean.

Figure 2 shows graphs of recorded rainfall amounts and rainfall departures from mean monthly rainfall values that were averaged for the base period 1951-90. Periods of below average rainfall can be inferred from the graph when the departure from the mean monthly rainfall is less than zero. Rainfall for July 1995 was above the mean monthly rainfall for the month, but rainfall was below the respective mean monthly rainfall for August and September 1995. 


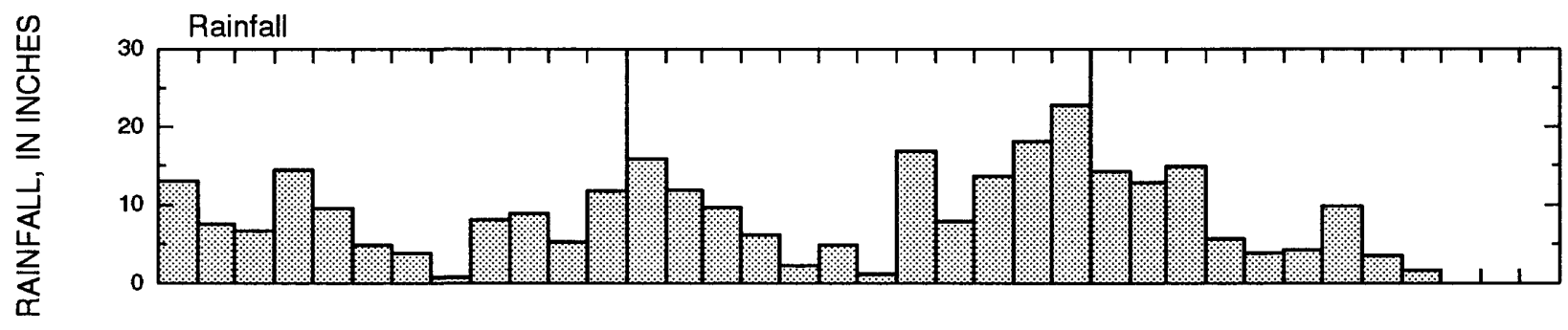

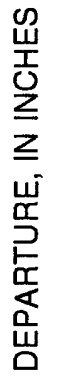

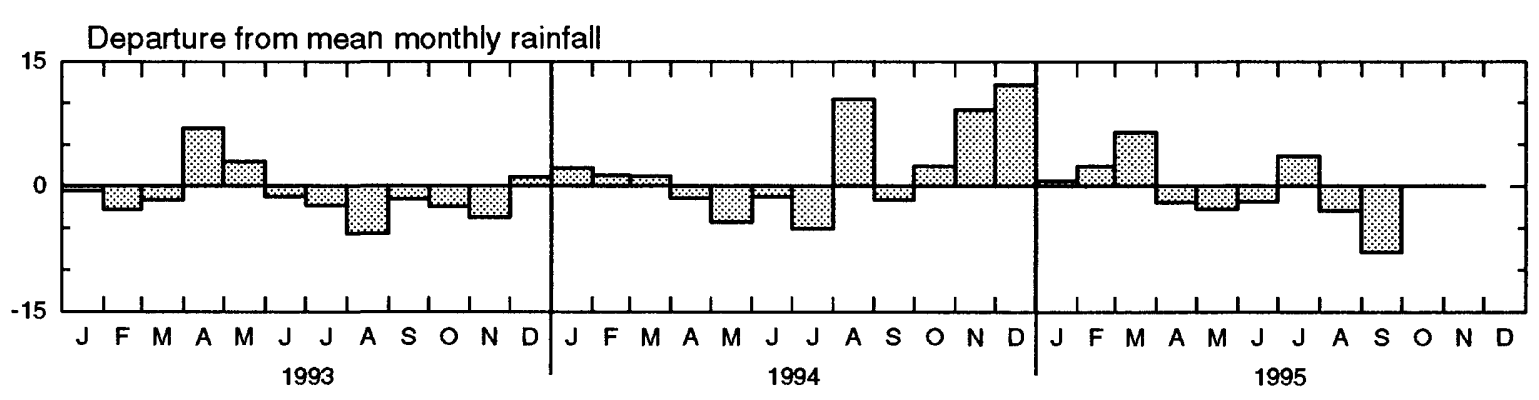

Figure 2. Monthly rainfall and monthly departure from mean monthly rainfall at Air Operations, Diego Garcia, January 1993 through September 1995. 


\section{GROUND-WATER WITHDRAWAL}

Background.--Withdrawal is measured by flow meters at all production wells and storage tanks in the water system, and is recorded daily. There are 102 production wells that are situated in five ground-water production areas, of which 80 wells are in the Cantonment area and 18 are in the Air Operations area (figs. A1, A2). The wells in the Cantonment area are further divided into sub-groups, and the measured ground-water withdrawals are reported as such in this summary.

Pumpage from the Cantonment area increased in 1991 when the area began supplying an extra demand due to decreased pumpage at Air Operations (Torikai, 1995). Ten wells at Air Operations were temporarily closed from May 1991 through April 1992 due to an underground fuel pipeline leak near those wells. Pumping resumed at four wells in the water-supply system in May 1992, but six Air Operations wells still do not contribute to the water supply because of the close proximity to the fuel leak. Ground-water withdrawals from the other ground-water production areas have been held at fairly steady rates since 1992 .

Recent trends.--Figure 3 shows time-series graphs of monthly mean withdrawal islandwide and in each ground-water production area from January 1993 through September 1995. Patterns of withdrawal during the third quarter of 1995 have not changed significantly since 1993 in all areas except the GEODSS site, which had an increase in withdrawal of about $1,000 \mathrm{gal} / \mathrm{d}$. Total islandwide withdrawal decreased from $919,400 \mathrm{gal} / \mathrm{d}$ during July through September 1994 to 888,500 gal/d during July through September 1995. 


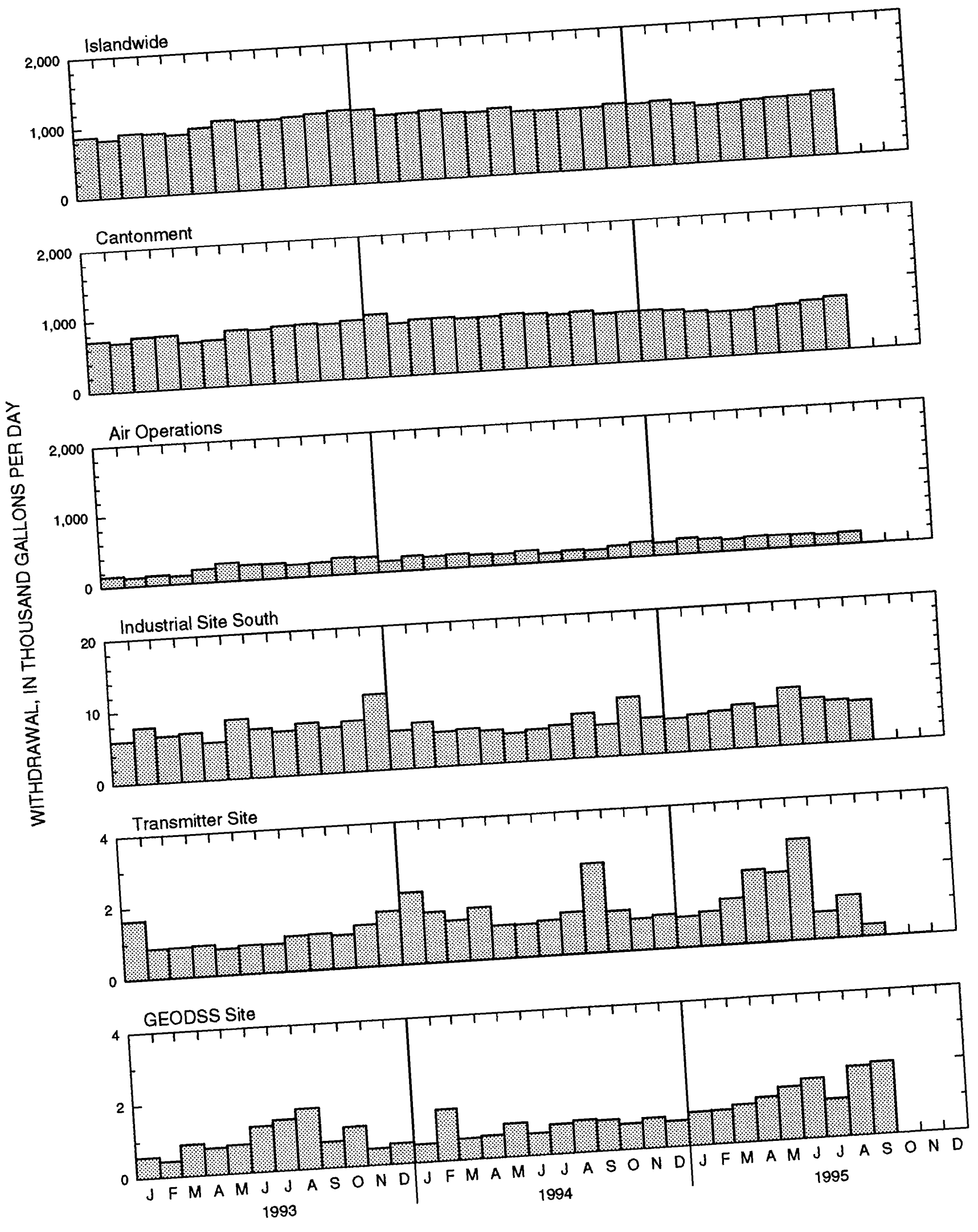

Figure 3. Monthly mean ground-water withdrawal islandwide and in the ground-water production areas, Diego Garcia, January 1993 through September 1995. 


\section{CHLORIDE CONCENTRATION OF PUMPED GROUND WATER}

Background.--Chloride concentration is used as a quantitative measure of salinity in this report. Chloride concentration in seawater at Diego Garcia is about $19,500 \mathrm{mg} / \mathrm{L}$ whereas a concentration of $250 \mathrm{mg} / \mathrm{L}$ is the maximum contaminant level (MCL) under secondary drinkingwater standards (U.S. Environmental Protection Agency, 1991). Secondary standards are not enforceable limits, but instead establish goals for constituents that may affect the aesthetic qualities of drinking water, such as taste or color.

Water is sampled at weekly intervals at all wells and storage tanks in the production system. Water in the Air Operations tank is a blend of ground water withdrawn from wells in the Air Operations area only, whereas the Cantonment tank water is a mixture of ground water from wells in both the Air Operations and Cantonment areas. This composite tank transmits about 99 percent of total island pumpage. Thus, the chloride concentration of water sampled from the Cantonment tank is considered representative of the overall water supply.

Recent trends.--The chloride concentration of the composite water supply at the end of September 1995 was $51 \mathrm{mg} / \mathrm{L}$, well below the $250 \mathrm{mg} / \mathrm{L}$ secondary drinking-water standard. Chloride concentrations for the composite water supply ranged from 42 to $68 \mathrm{mg} / \mathrm{L}$ from July through September 1995 (fig. 4). Chloride concentrations of the composite water in the Cantonment tank have remained at less than $100 \mathrm{mg} / \mathrm{L}$ since 1990 , whereas the chloride concentration of water sampled from the Air Operations tank has fluctuated between about 50 to $200 \mathrm{mg} / \mathrm{L}$ since 1992 (Torikai, 1995).

During the third quarter of 1995, chloride concentrations of water from all five groundwater production areas leveled off following increases recorded during the first half of 1995. The third quarter (July through September) occurs during the transition from the annual dry season into the wet season.

Chloride concentrations from individual wells during the third quarter also remained fairly steady relative to concentrations recorded at the end of the second quarter (figs. $\mathrm{Cl}$ through C4). Concentrations at wells H5 and H7 (fig. C2), and at wells Q6 and AO-8 (figs. C3 and C4, respectively) increased during the third quarter (July through September 1995), but actually decreased by the end of September to within about $40 \mathrm{mg} / \mathrm{L}$ of levels recorded at the end of June 1995. 


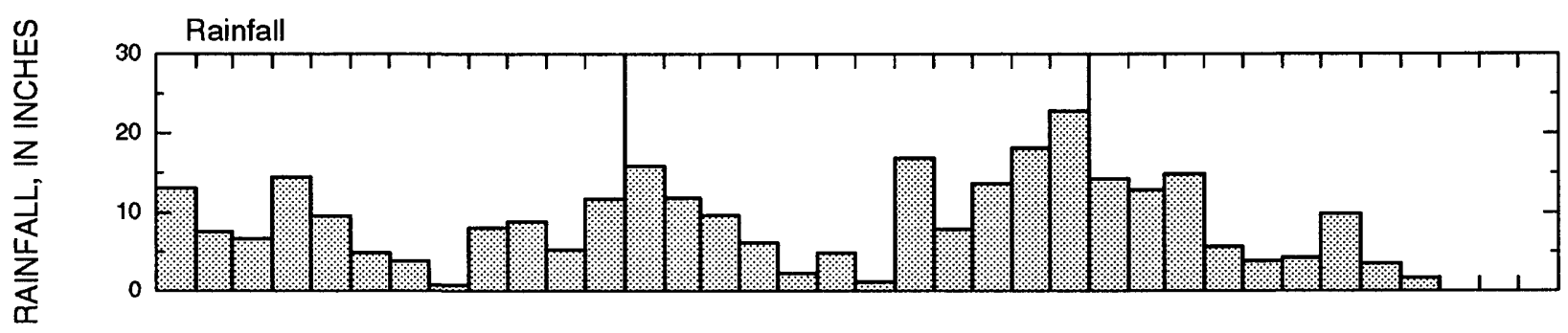

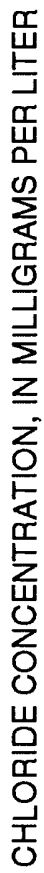

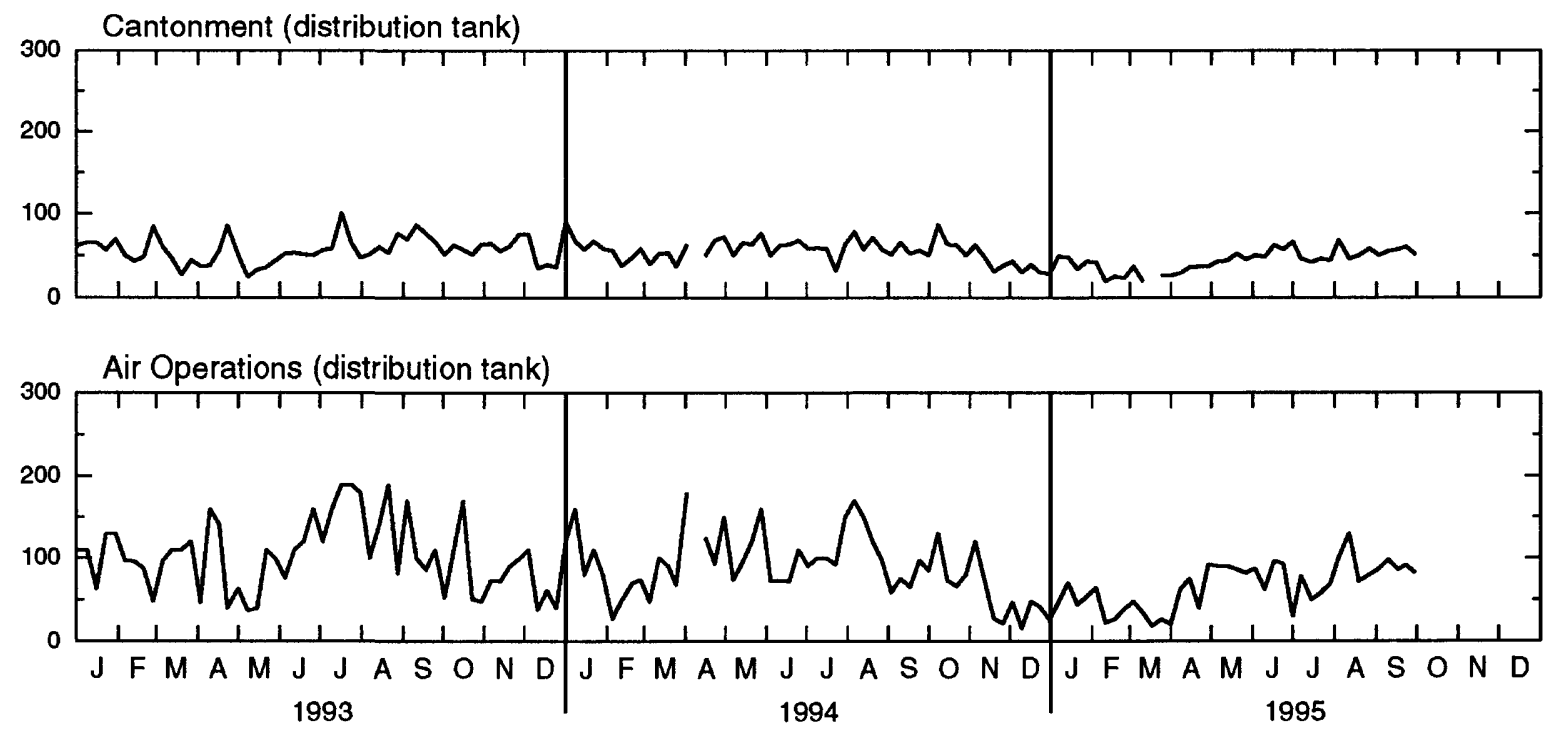

Figure 4. Chloride concentration of pumped water (sampled at weekly intervals) in the ground-water production areas, Diego Garcia, January 1993 through September 1995. Rainfall data are shown for comparison. 

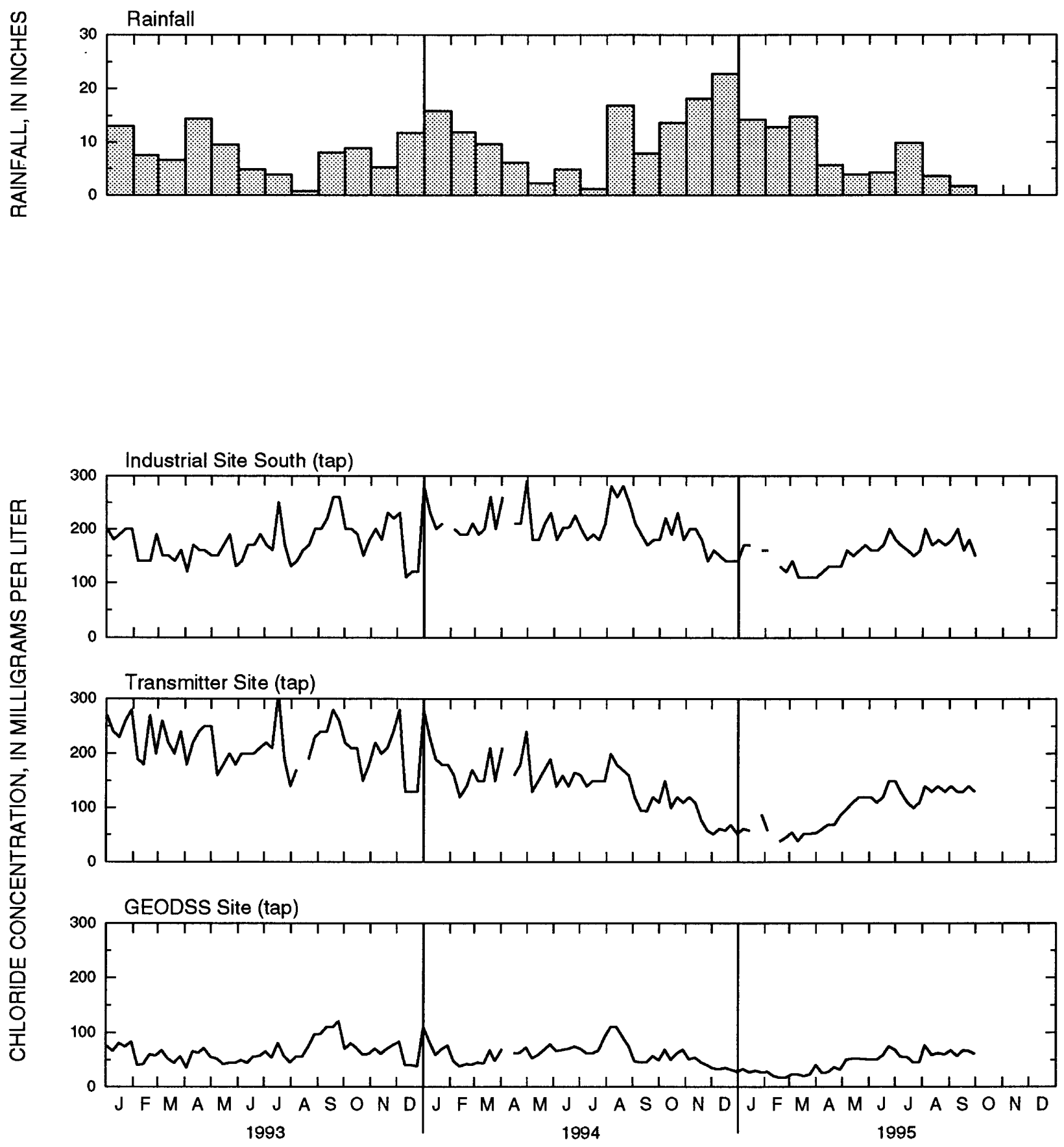

Figure 4 continued.--Chloride concentration of pumped water (sampled at weekly intervals) in the ground-water production areas, Diego Garcia, January 1993 through September 1995. Rainfall data are shown for comparison. 


\section{CHLORIDE CONCENTRATION OF GROUND WATER IN MONITORING WELLS}

Background.--Ground-water chloride concentration is measured monthly at 35 monitoring-well sites to help estimate freshwater-lens thickness and indicate possible saltwater upconing due to above average pumping (figs. A3, A4). Each site comprises several wells, with each well having a short screened (open) interval that bottoms at a different depth. The deeper wells typically tap the freshwater-saltwater mixing zone that underlies the freshwater lenses.

Recent trends.--Monitoring sites AW16 and BW09 were selected to show trends in ground-water chloride concentration at Cantonment and Air Operations Areas, respectively. Figures 5 and 6 show time-series graphs of chloride concentration at three depths at the Cantonment and Air Operations sites, respectively, with rainfall data included in the figures for climatic reference.

Chloride concentrations of the water increased at both sites during July through September 1995. The increases were recorded at the two deeper wells at each site, with the deepest well at each site showing the largest increase in concentration. The chloride concentration at the deepest well at sites AW16 and BW09 increased about 2,000 and $500 \mathrm{mg} / \mathrm{L}$, respectively. This continues a trend of increasing chloride concentrations at the deepest monitoring wells since April 1995. The chloride concentration at the intermediate well at BW09 increased about $100 \mathrm{mg} / \mathrm{L}$ since June 1995. 

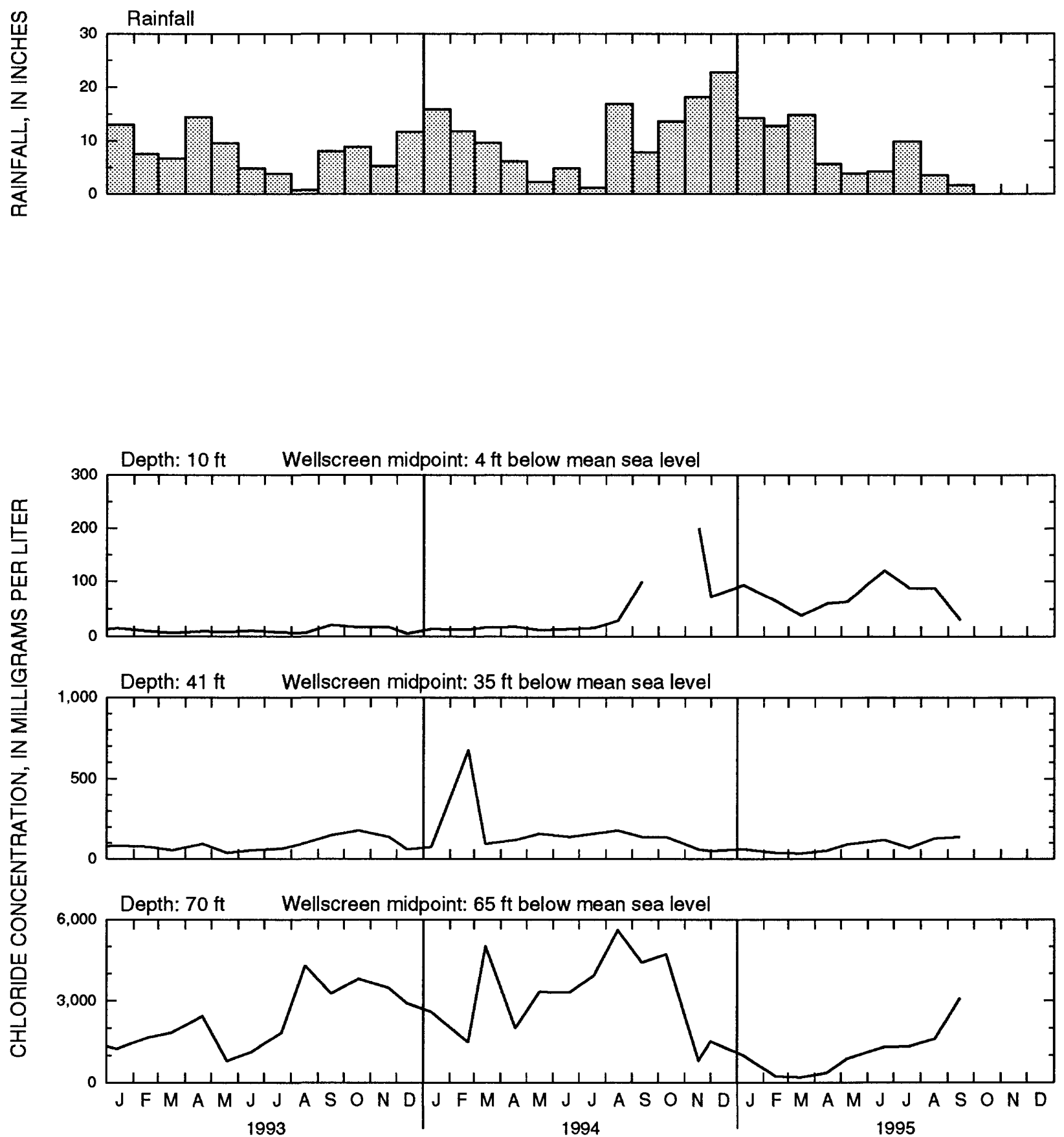

Figure 5. Chloride concentration of ground water (sampled at monthly intervals) in monitoring wells at site AW16 at Cantonment, Diego Garcia, January 1993 through September 1995. Rainfall data are shown for comparison. 

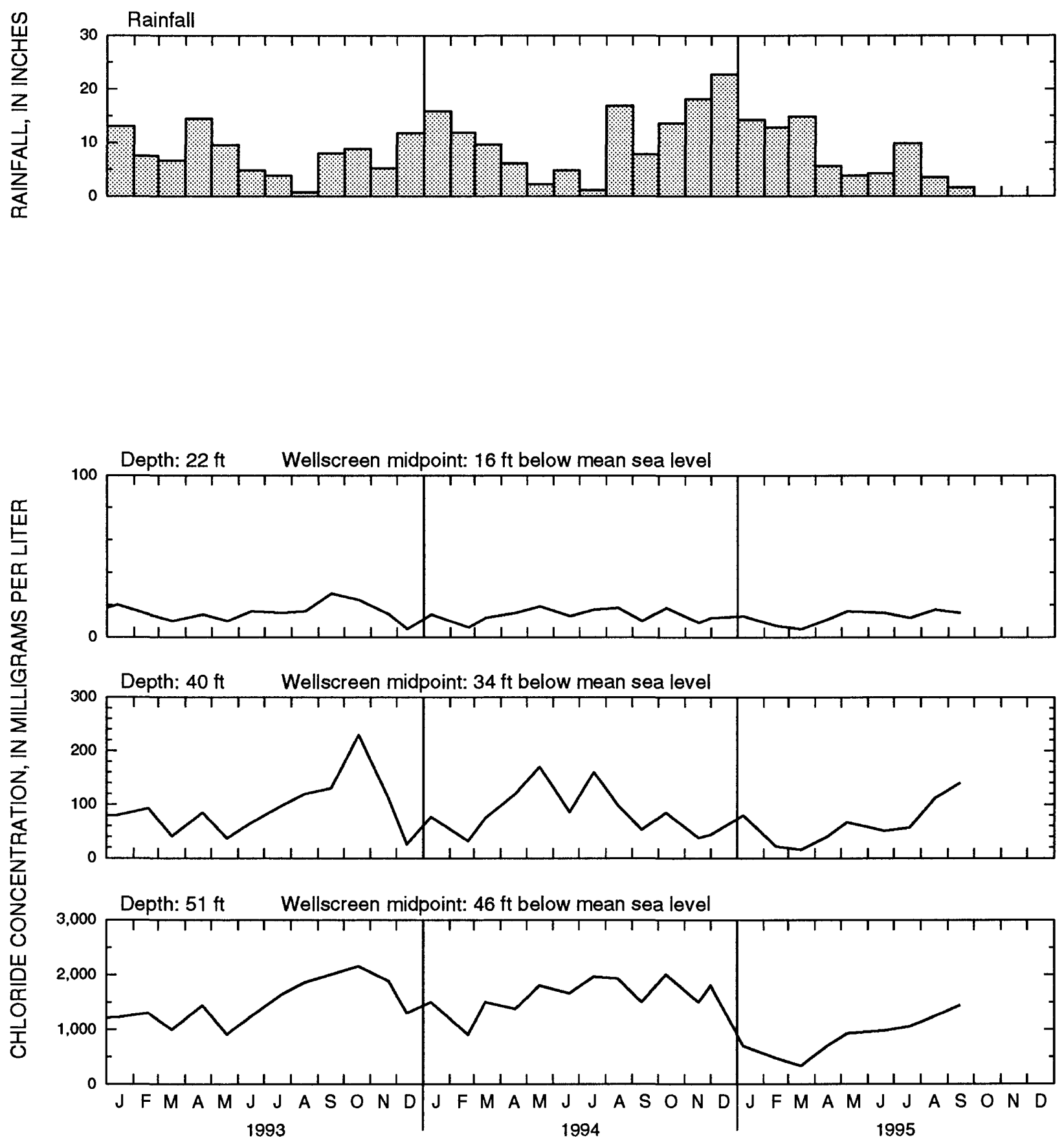

Figure 6. Chloride concentration of ground water (sampled at monthly intervals) in monitoring wells at site BW09 at Air Operations, Diego Garcia, January 1993 through September 1995. Rainfall data are shown for comparison. 


\section{FUEL-DIVERSION PROGRAM AT AIR OPERATIONS}

Background.--The normal pattern of ground-water withdrawal at Air Operations has been disrupted since May 1991 by a jet-fuel leak at the South Ramp Parking Apron (fig. A2). Wells AO-10 through AO-15 were shut down from May 1991 to April 1992, but have since been used in the closed recirculation loop of withdrawal and injection. In April 1992, a program was initiated to hydraulically divert fuel away from the production wells. The fuel-diversion program consists of pumping about $150,000 \mathrm{gal} / \mathrm{d}$ of water from wells AO-14 and AO-15 and directing this water through the common collection main to the wells nearest the leak (AO-10, $11,12)$, where it is injected back into the aquifer. Well AO-13 has remained shut down since 1991.

Injection data for wells AO-10, 11, 12 from May 10, 1993 through September 1994 are actual water-meter readings. From April 1992 through early May 1993, meter readings of injection were not available, and daily injection at each of the three wells was estimated to be one-third of the total daily withdrawal from wells AO-13, 14, 15 which provided the injectionsupply water. Monthly mean withdrawal and injection at wells AO-10 through AO-15 are shown in figure 7.

Recent trends.--Withdrawal and injection rates for wells in the hydraulic-diversion program did not change during the period July through September 1995. Target withdrawal and injection rates are listed in table 1 for wells AO-10 through AO-15. Daily mean withdrawal and injection rates for these wells are also shown.

Table 1: Target and actual withdrawal and injection rates for hydraulic-diversion program. [Injection is denoted by negative values; all values are in gallons per day.]

\begin{tabular}{ccc}
\hline Well & Target rates & $\begin{array}{c}\text { Daily mean rates, } \\
\text { July through September 1995 }\end{array}$ \\
\hline AO-10 & $-30,000$ & $-27,100$ \\
AO-11 & $-50,000$ & $-52,500$ \\
AO-12 & $-70,000$ & $-67,500$ \\
AO-13 & 0 & 0 \\
AO-14 & 70,000 & 72,700 \\
AO-15 & 80,000 & 81,900 \\
\hline
\end{tabular}




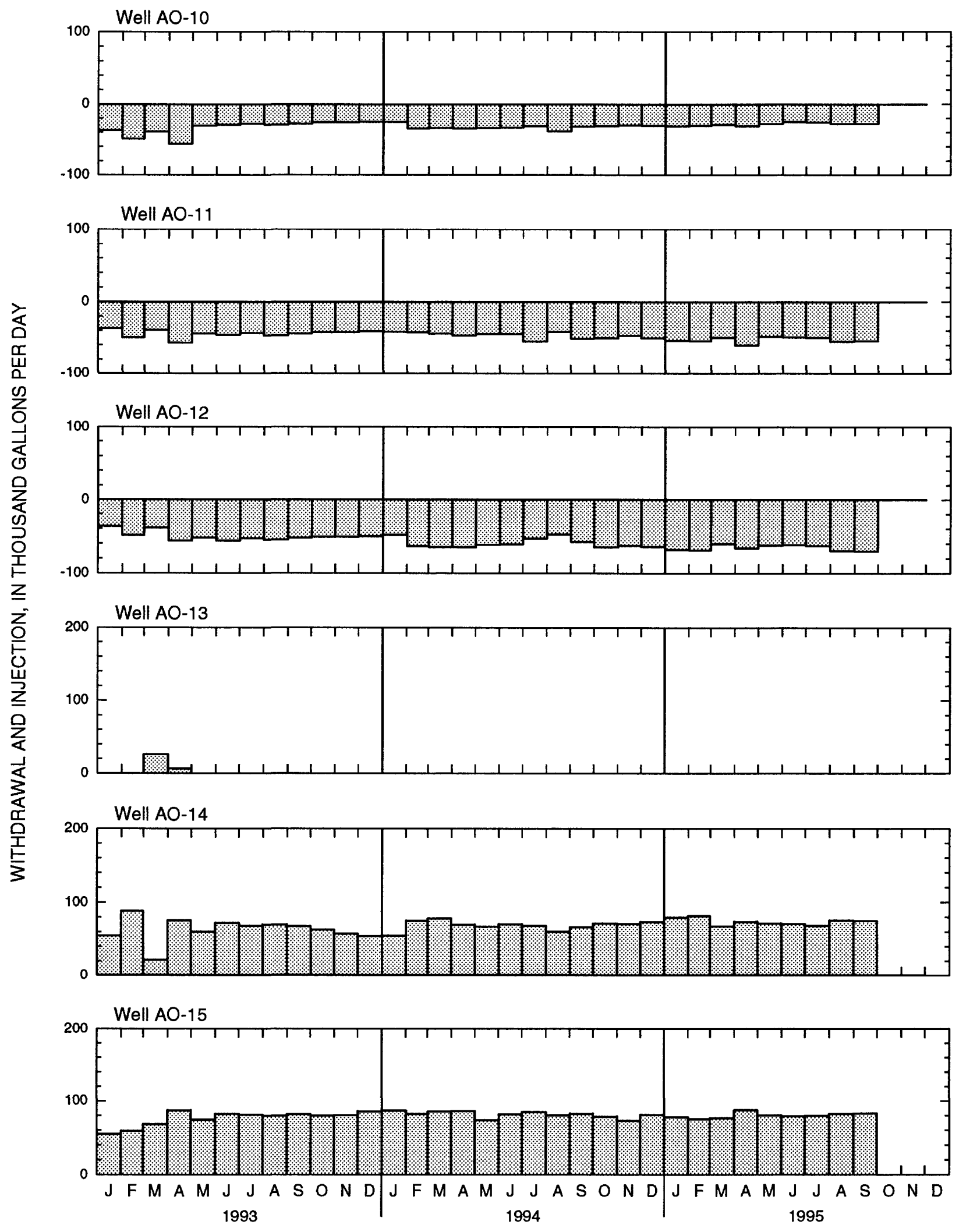

Figure 7. Monthly mean ground-water withdrawal and injection at wells AO-10 through AO-15 at Air Operations, Diego Garcia, January 1993 through September 1995. Injection is plotted as negative. 


\title{
H Y D R OLOG I C - D A T A SECTION
}

\author{
TYPES OF DATA INCLUDED
}

\begin{abstract}
A. Maps of production and monitoring wells at Cantonment and Air Operations
B. Graphs of monthly mean ground-water withdrawal, January 1993 through September 1995

C. Graphs of chloride concentration of pumped water, January 1993 through September 1995
\end{abstract}

\section{DESCRIPTIONS OF PRINCIPAL PRODUCTION SOURCES AT CANTONMENT AND AIR OPERATIONS AREAS}

\section{Cantonment Area}

1. Modules A, C through $\mathrm{L}$ - each module is a well field of five to eight vertical wells that are pumped to a common collection/transfer tank.

2. Module B is a horizontal well with a collection/transfer tank; has not pumped since August 1986.

3. Wells $\mathrm{H} 1$ through $\mathrm{H} 7$ are horizontal wells.

4. Quad wells are a well field of four vertical wells; originally, six wells drilled.

5. Jungle wells are a well field of 11 vertical wells; have not pumped since February 1987.

\section{Air Operations Area}

1. Wells AO-2 through AO-5 are vertical wells.

2. Wells AO-6 through AO-9 are horizontal wells.

3. Wells AO-10 through AO-12 are horizontal wells; currently receiving injection water to divert fuel contaminants from a nearby leak. No samples are currently collected for chloride-concentration analysis.

4. Wells AO-13 through AO-15 are horizontal wells; AO-14 and AO-15 are currently pumping water to injection wells AO-10 through AO-12, while AO-13 is not pumping.

5. AO-16 through AO-19 are horizontal wells. 


\section{SECTION A}

\section{Maps of production and monitoring wells at Cantonment and Air Operations}



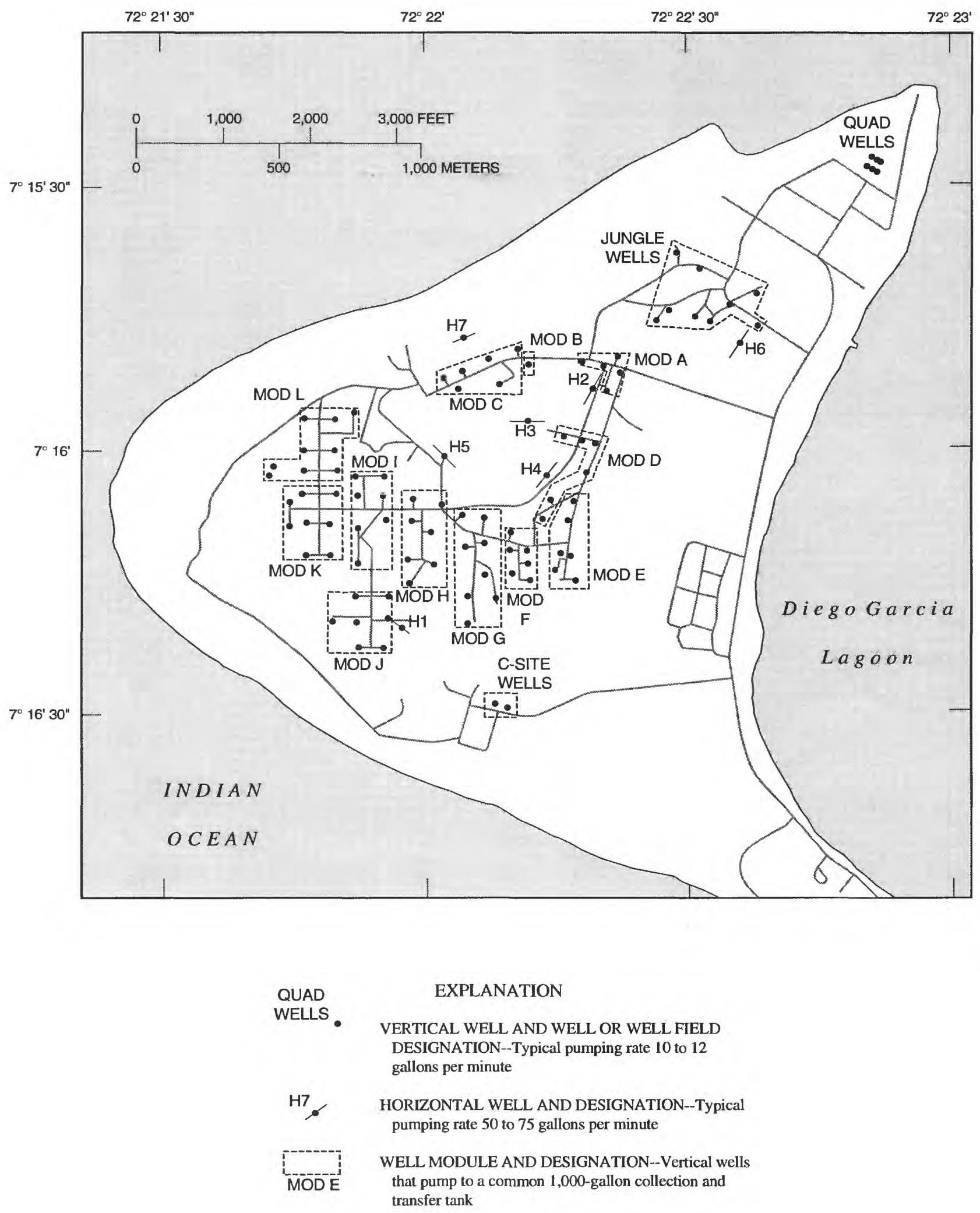

Figure A1. Ground-water production wells and well fields at Cantonment, Diego Garcia. 


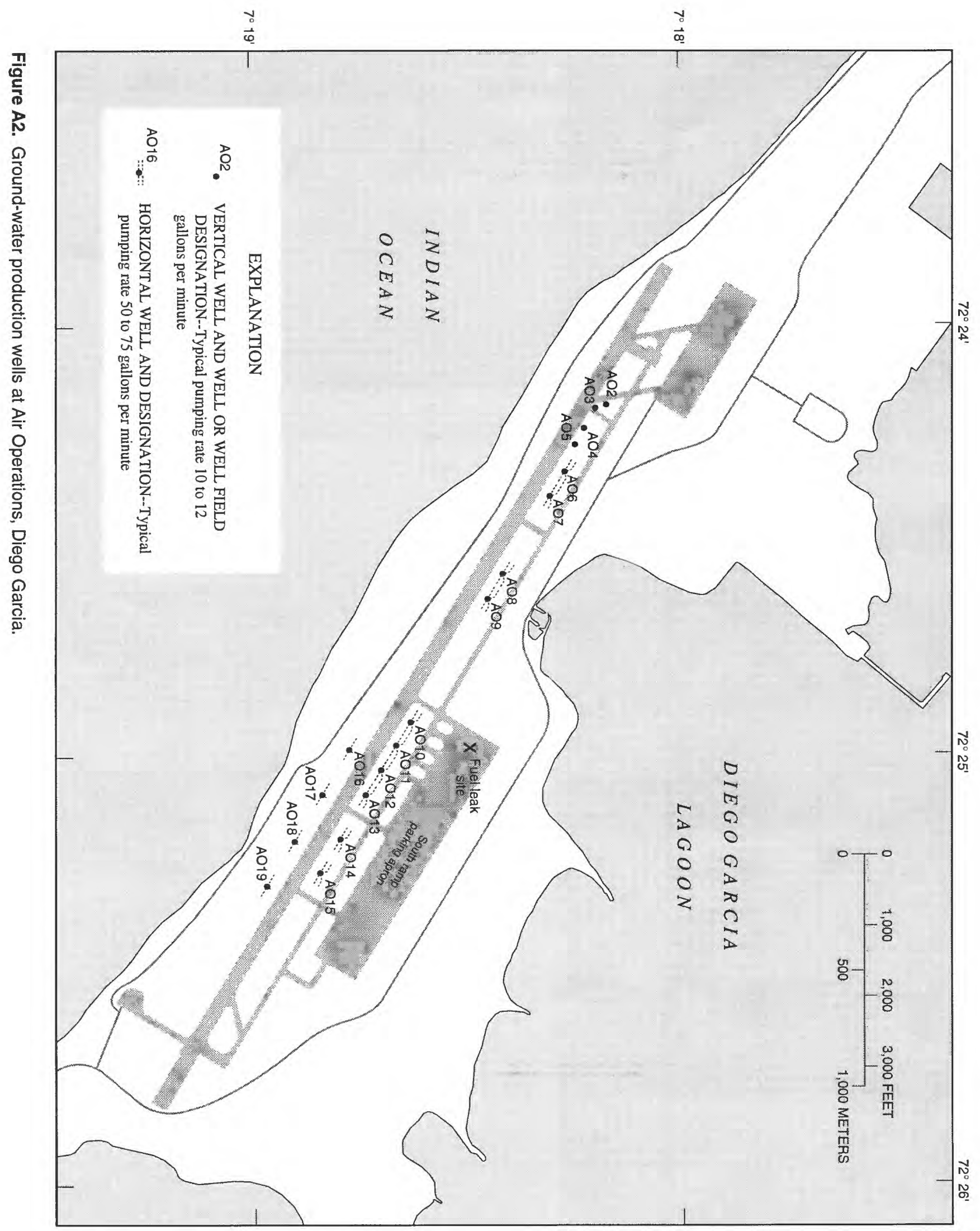




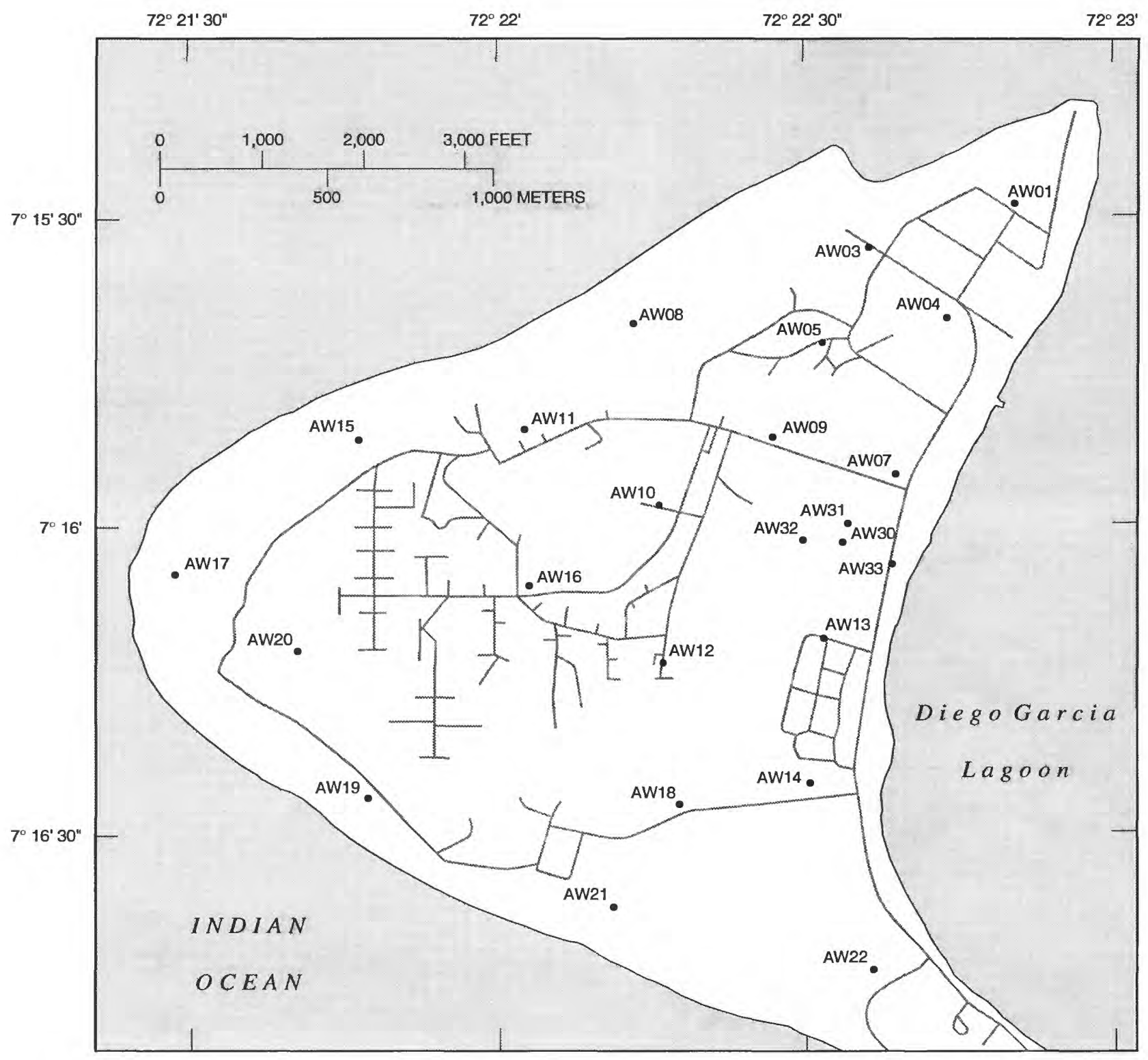

\section{EXPLANATION}

AW21 MONITORING SITE AND DESIGNATION--Consisting of two or more monitoring wells with short ( 2 to 5 foot) open intervals of different depths

Figure A3. Monitoring wells at Cantonment, Diego Garcia. 


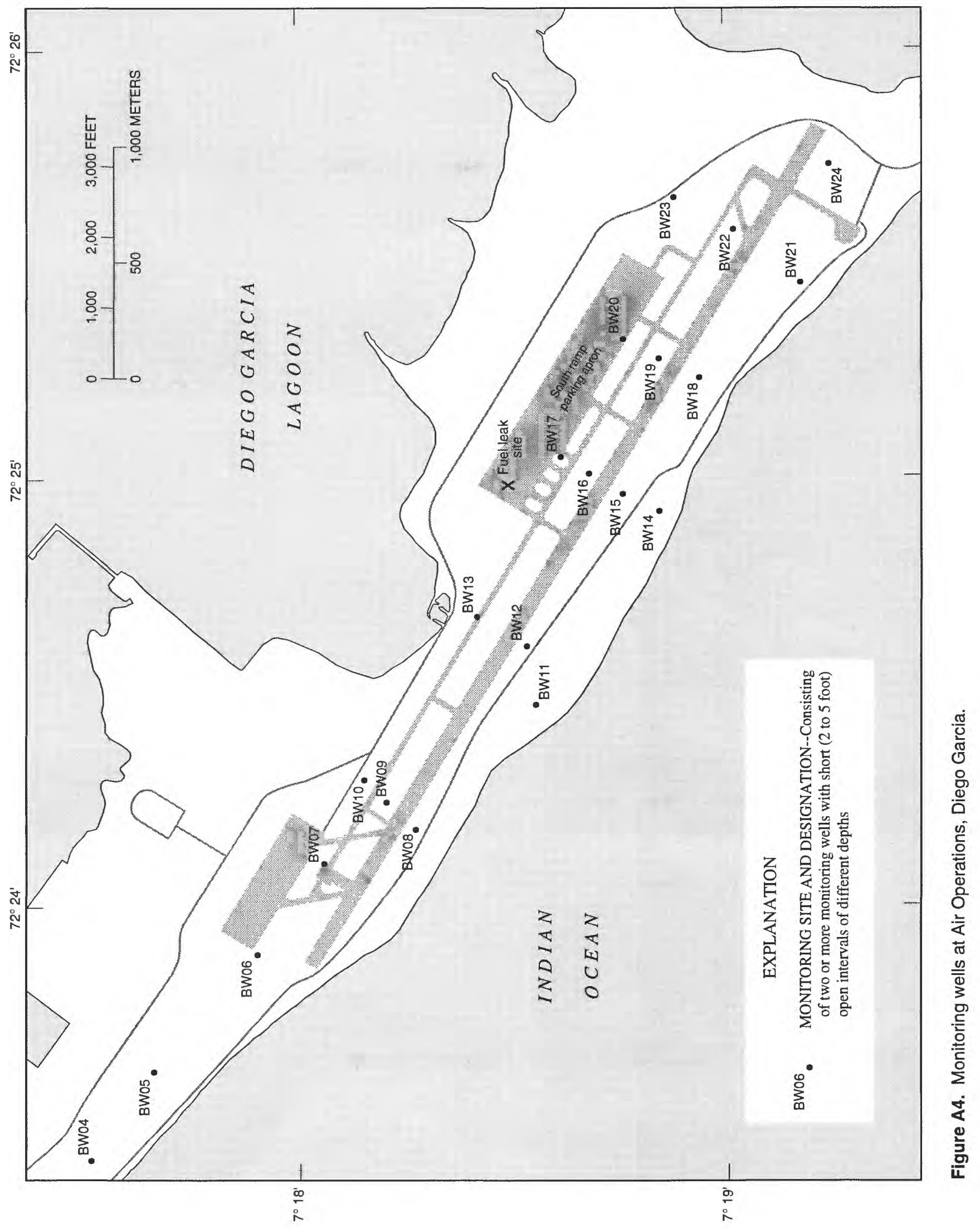




\section{SECTION B}

\section{Graphs of monthly mean ground-water withdrawal, January 1993 through September 1995}




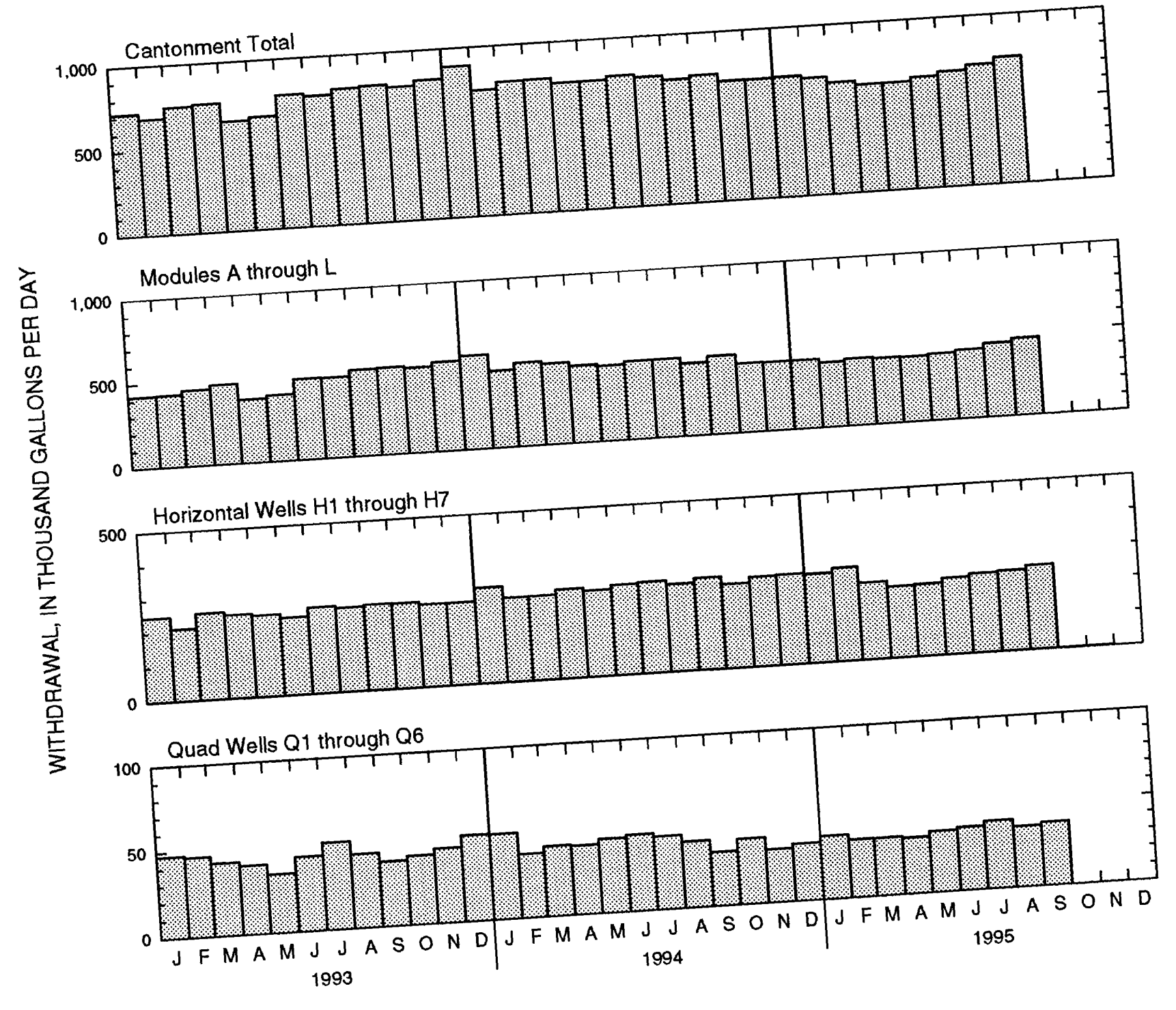

Figure B1. Monthly mean ground-water withdrawal at Cantonment, Diego Garcia, January 1993 through September 1995. 

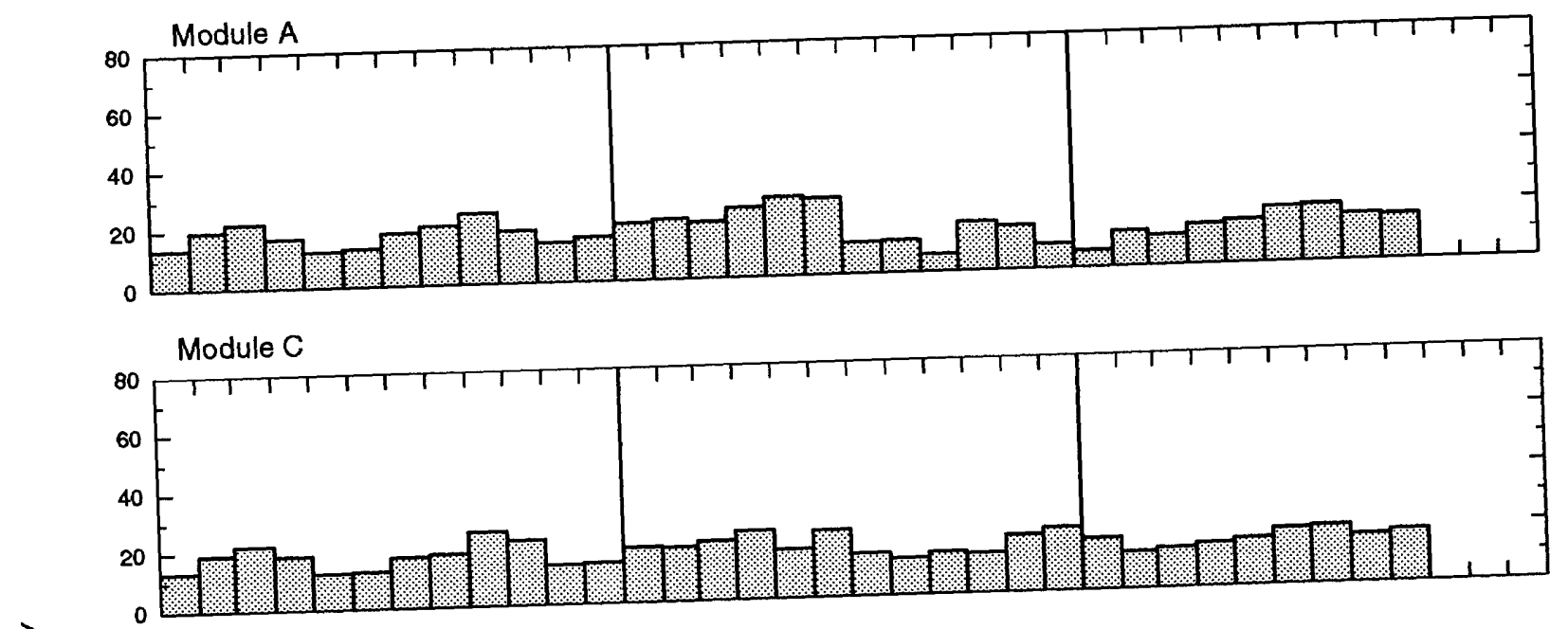

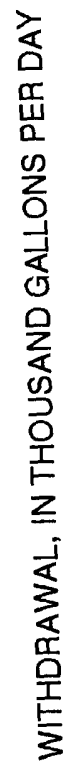
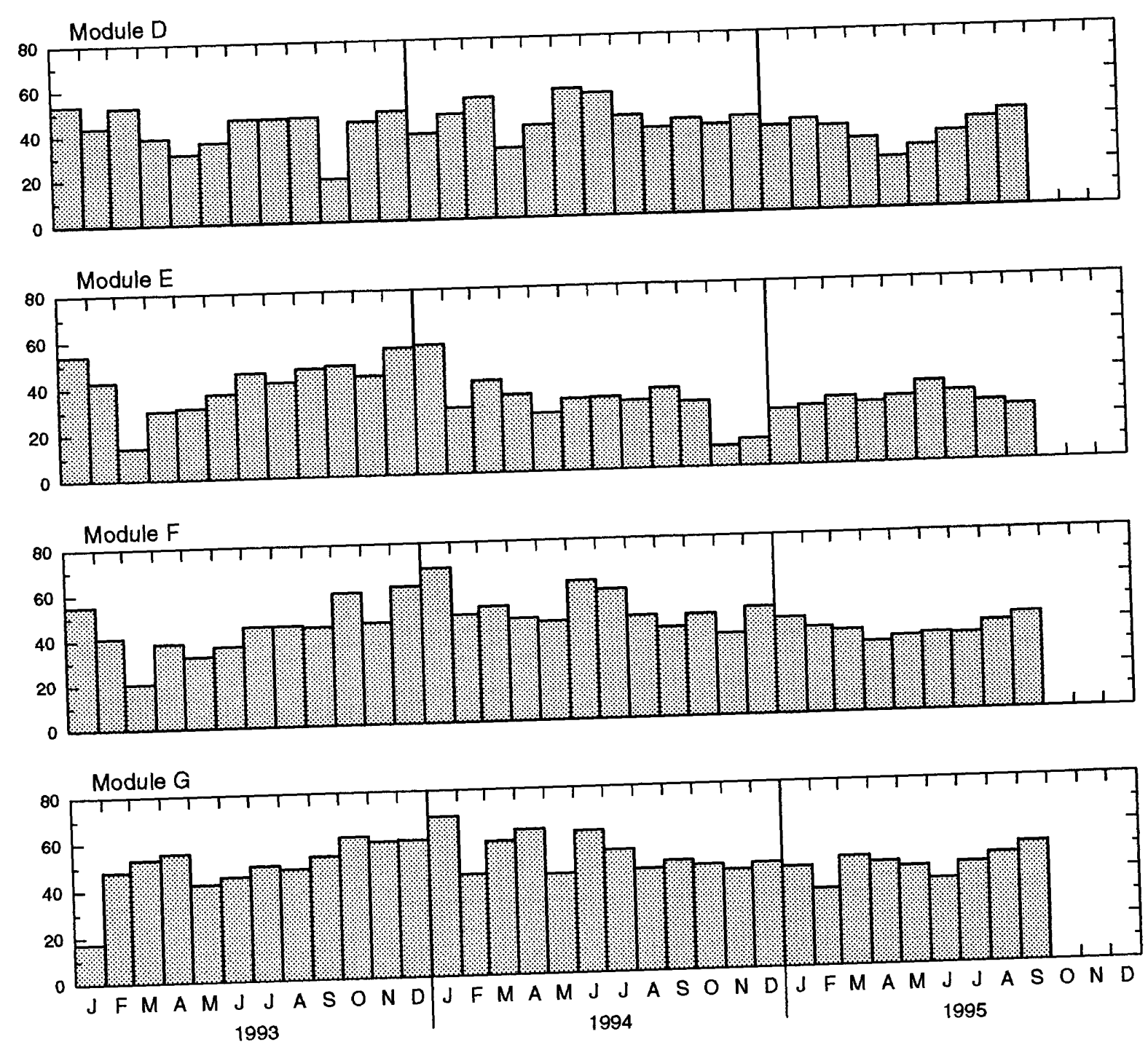

Figure B2. Monthly mean ground-water withdrawal at Modules A through L at Cantonment, Diego Garcia, January 1993 through September 1995. 

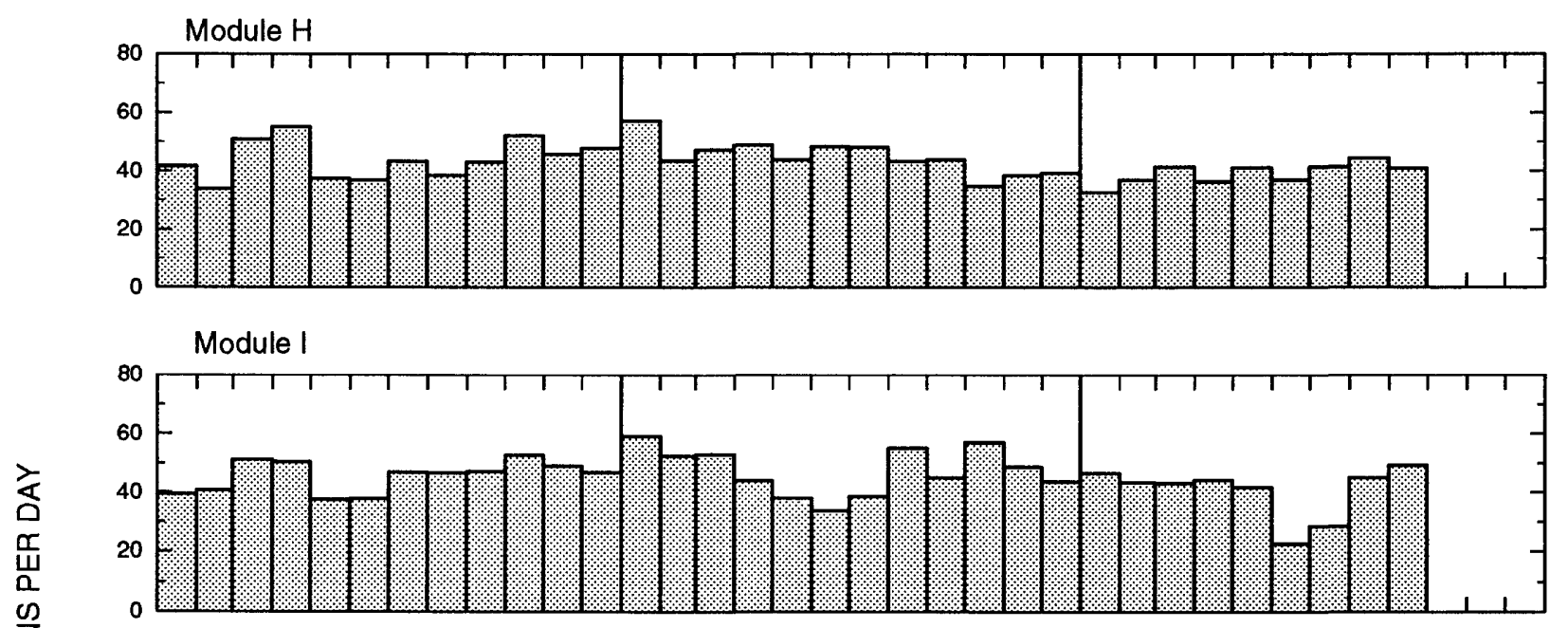

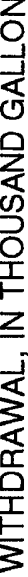
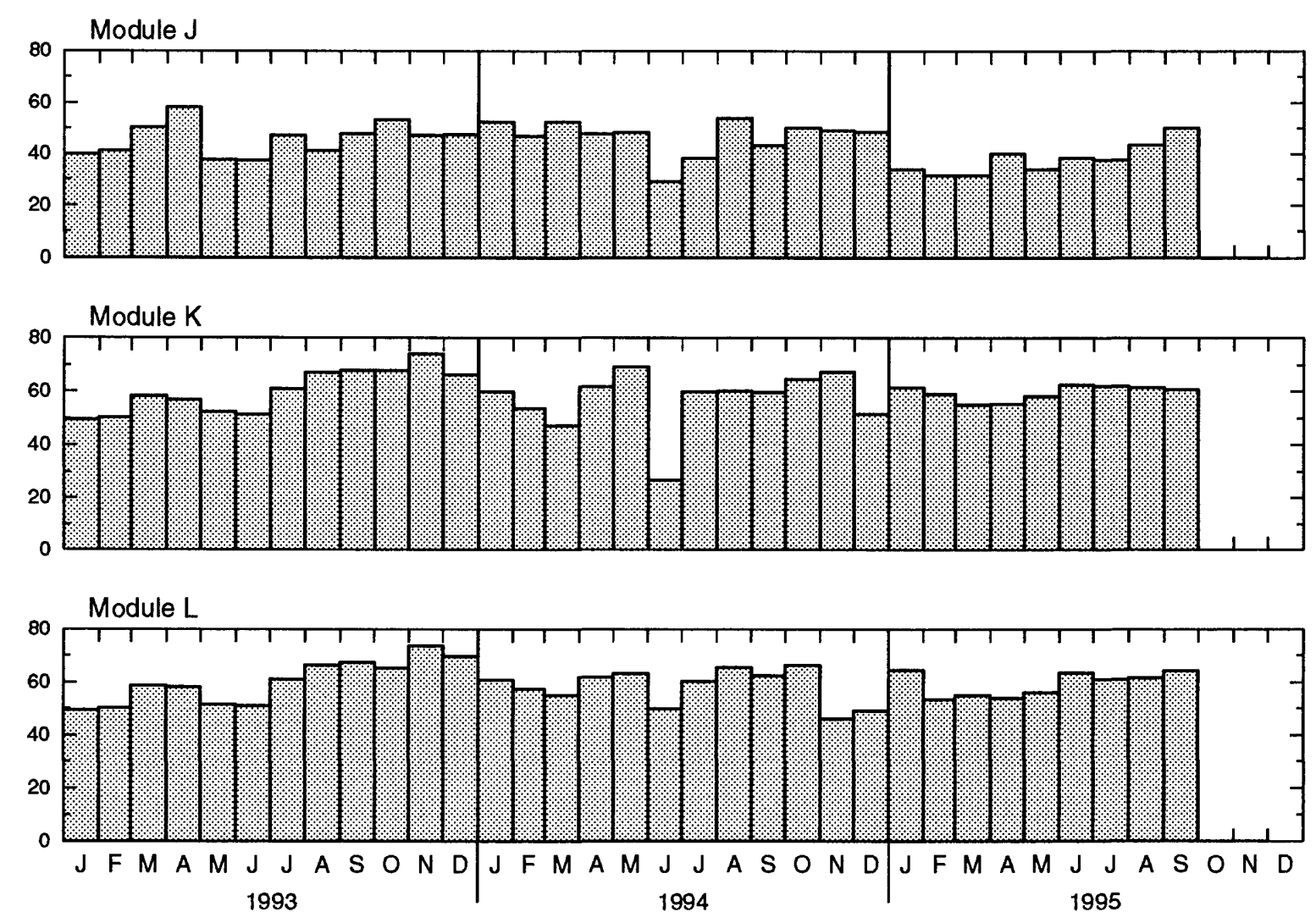

Figure B2 continued.--Monthly mean ground-water withdrawal at Modules A through $\mathrm{L}$ at Cantonment, Diego Garcia, January 1993 through September 1995. 

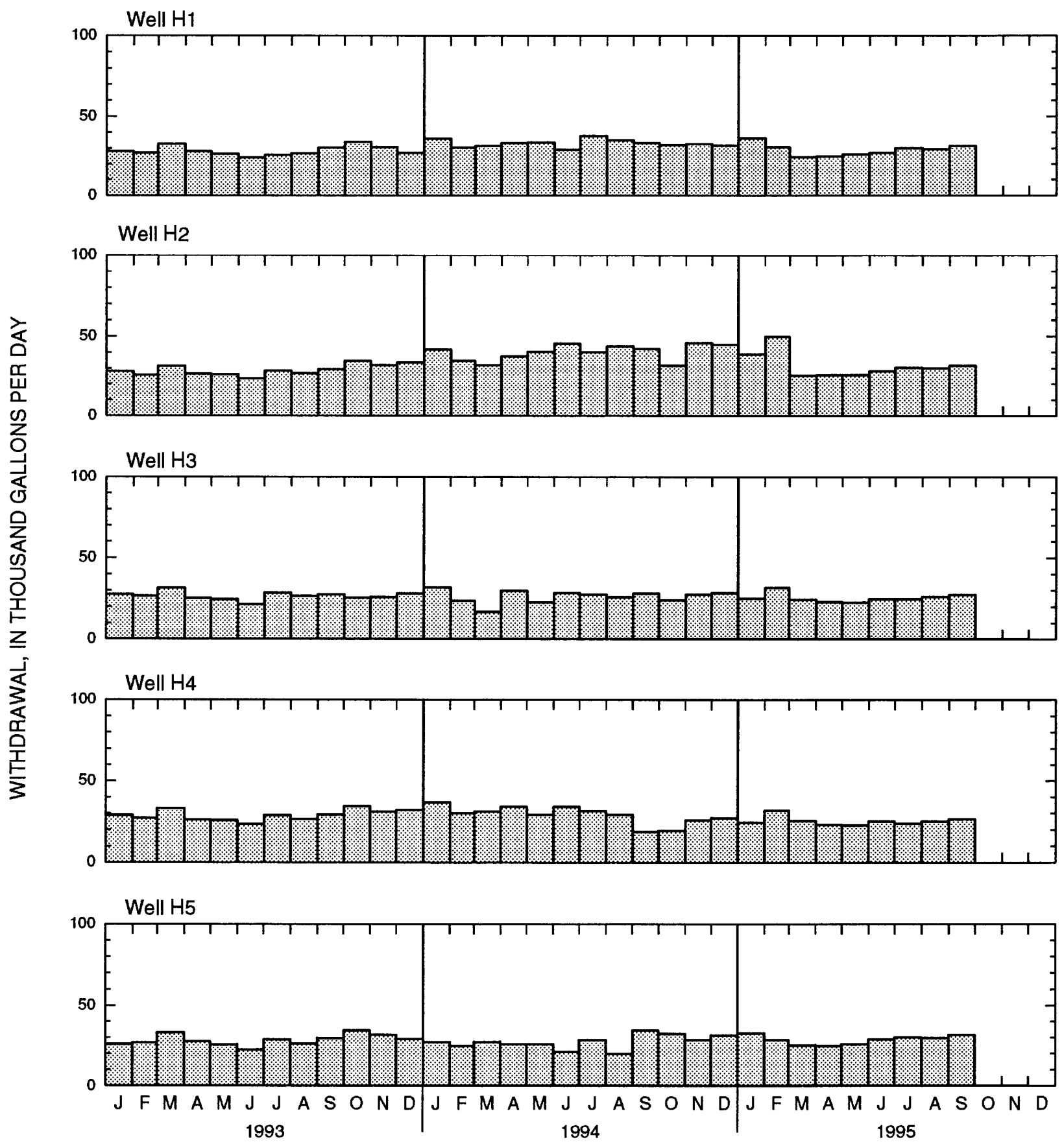

Figure B3. Monthly mean ground-water withdrawal at wells $\mathrm{H} 1$ through $\mathrm{H} 7$ at Cantonment, Diego Garcia, January 1993 through September 1995. 


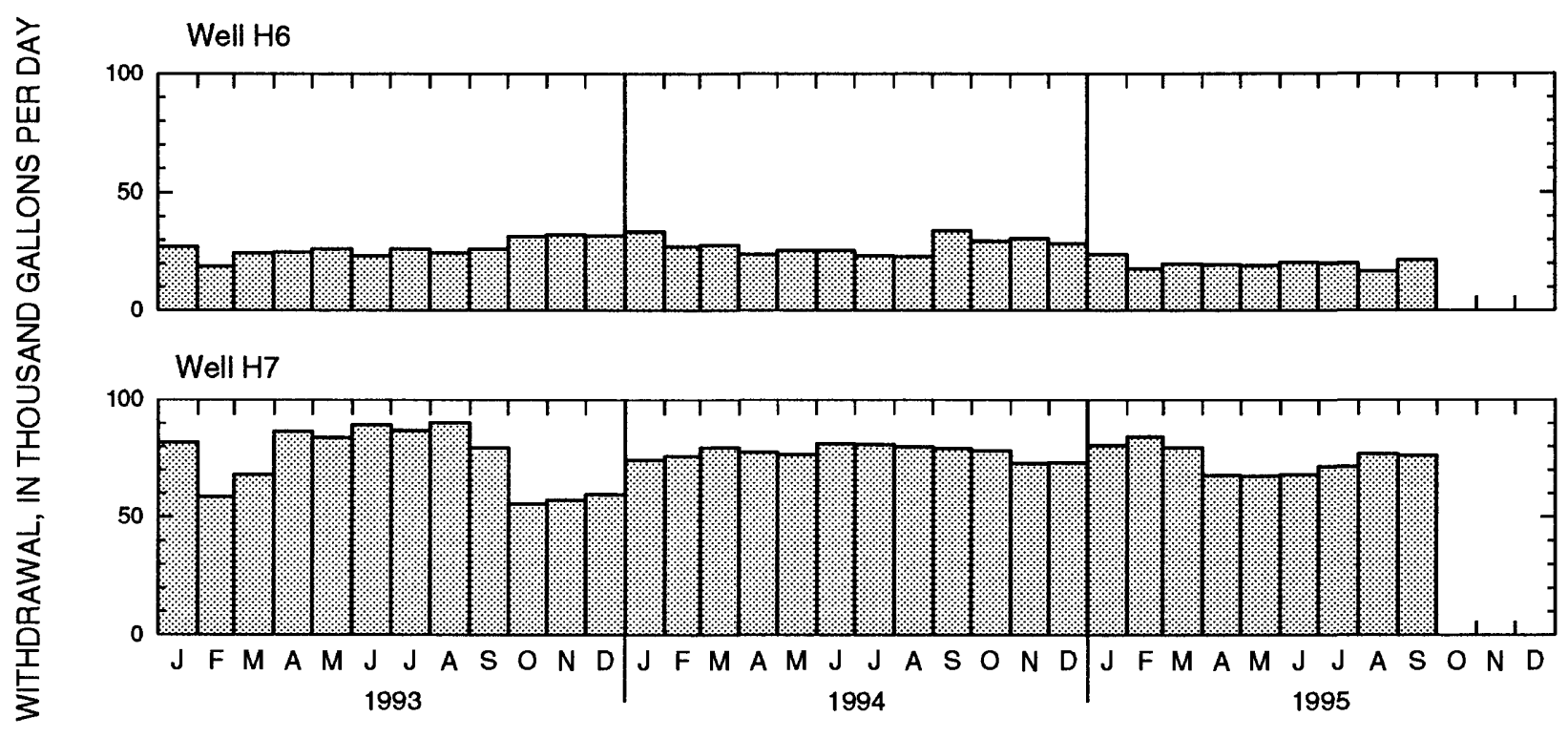

Figure B3 continued.--Monthly mean ground-water withdrawal at wells $\mathrm{Hl}$ through $\mathrm{H} 7$ at Cantonment, Diego Garcia, January 1993 through September 1995. 

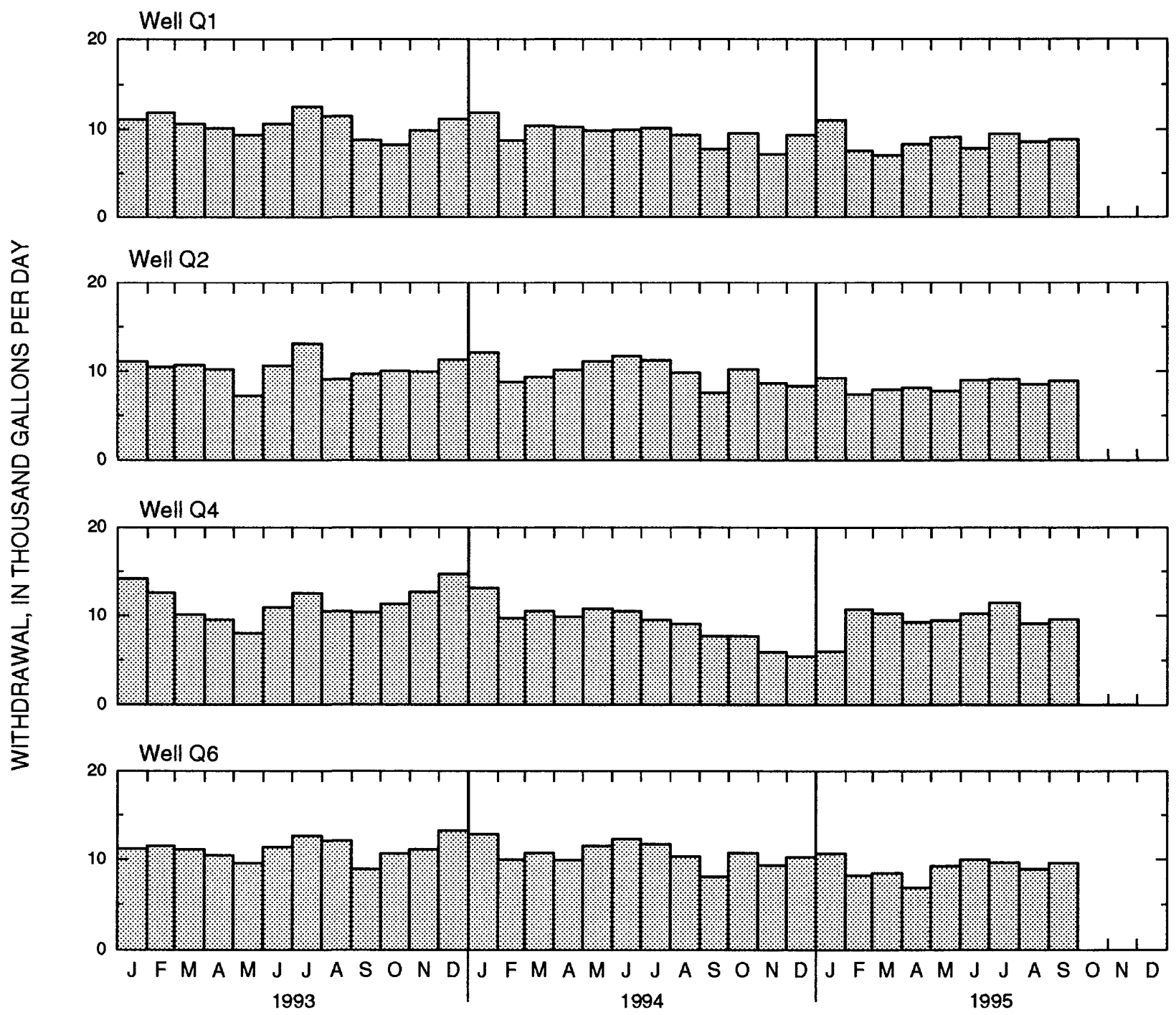

Figure B4. Monthly mean ground-water withdrawal at wells Q1, Q2, Q4, and Q6 at Cantonment, Diego Garcia, January 1993 through September 1995. 

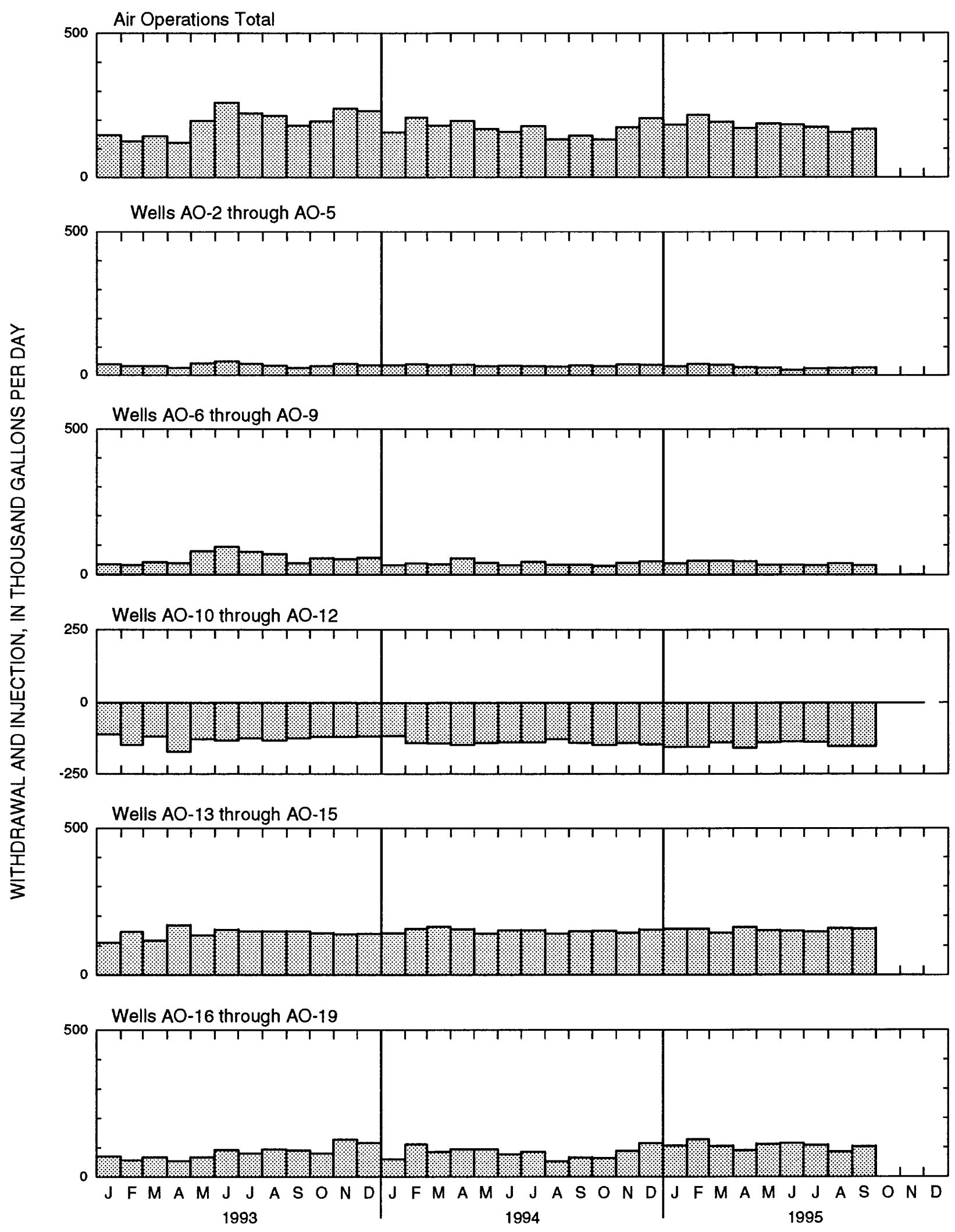

Figure B5. Monthly mean ground-water withdrawal and injection at Air Operations, Diego Garcia, January 1993 through September 1995. Injection is plotted as negative. 


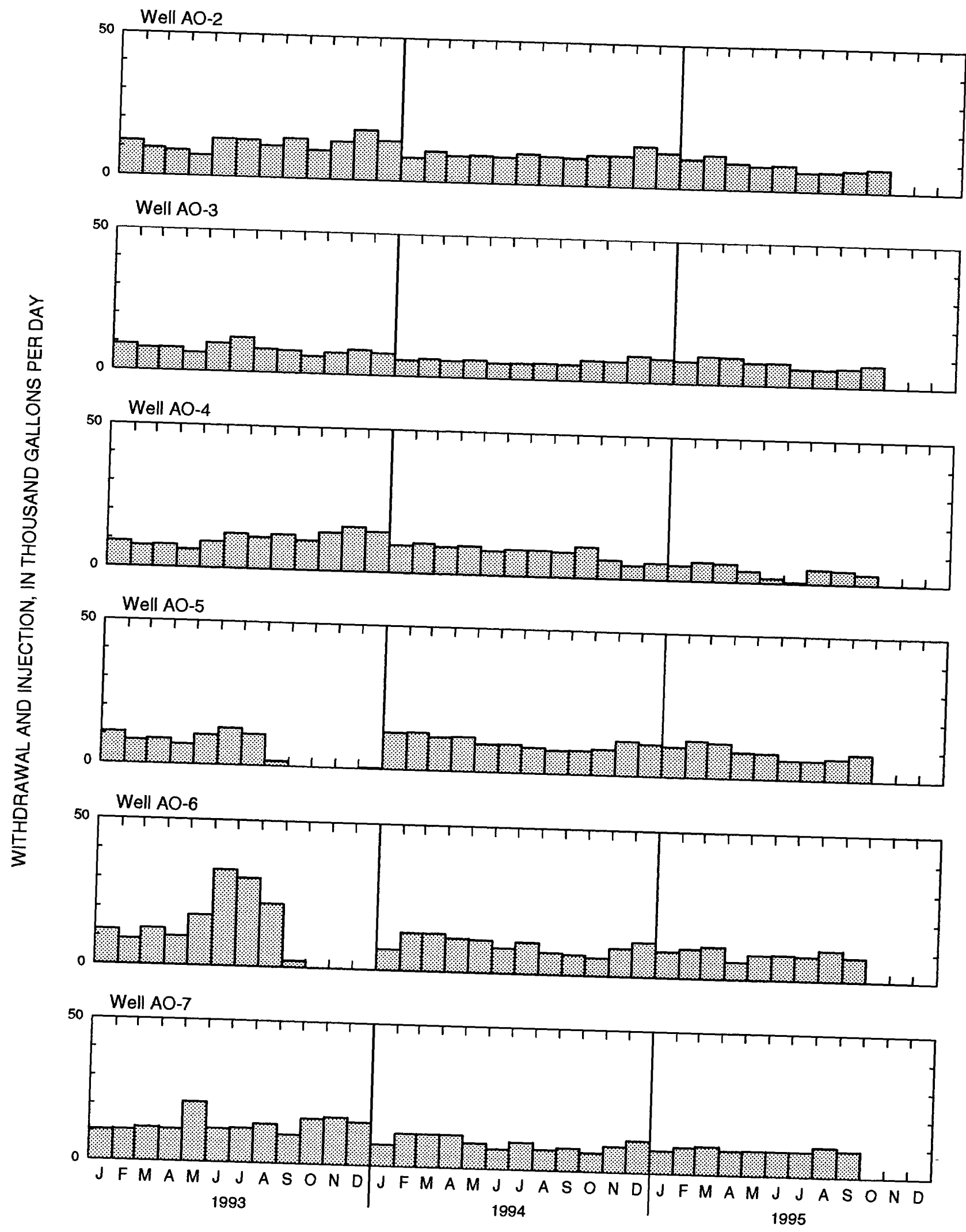

Figure B6. Monthly mean ground-water withdrawal and injection at wells AO-2 through AO-19 at Air Operations, Diego Garcia, January 1993 through September 1995. Injection is plotted as negative. 


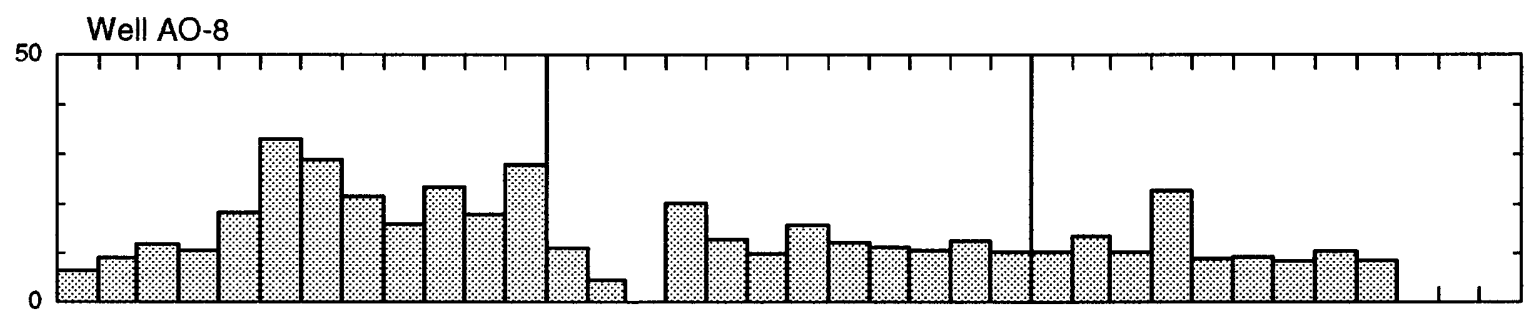

Well AO-9
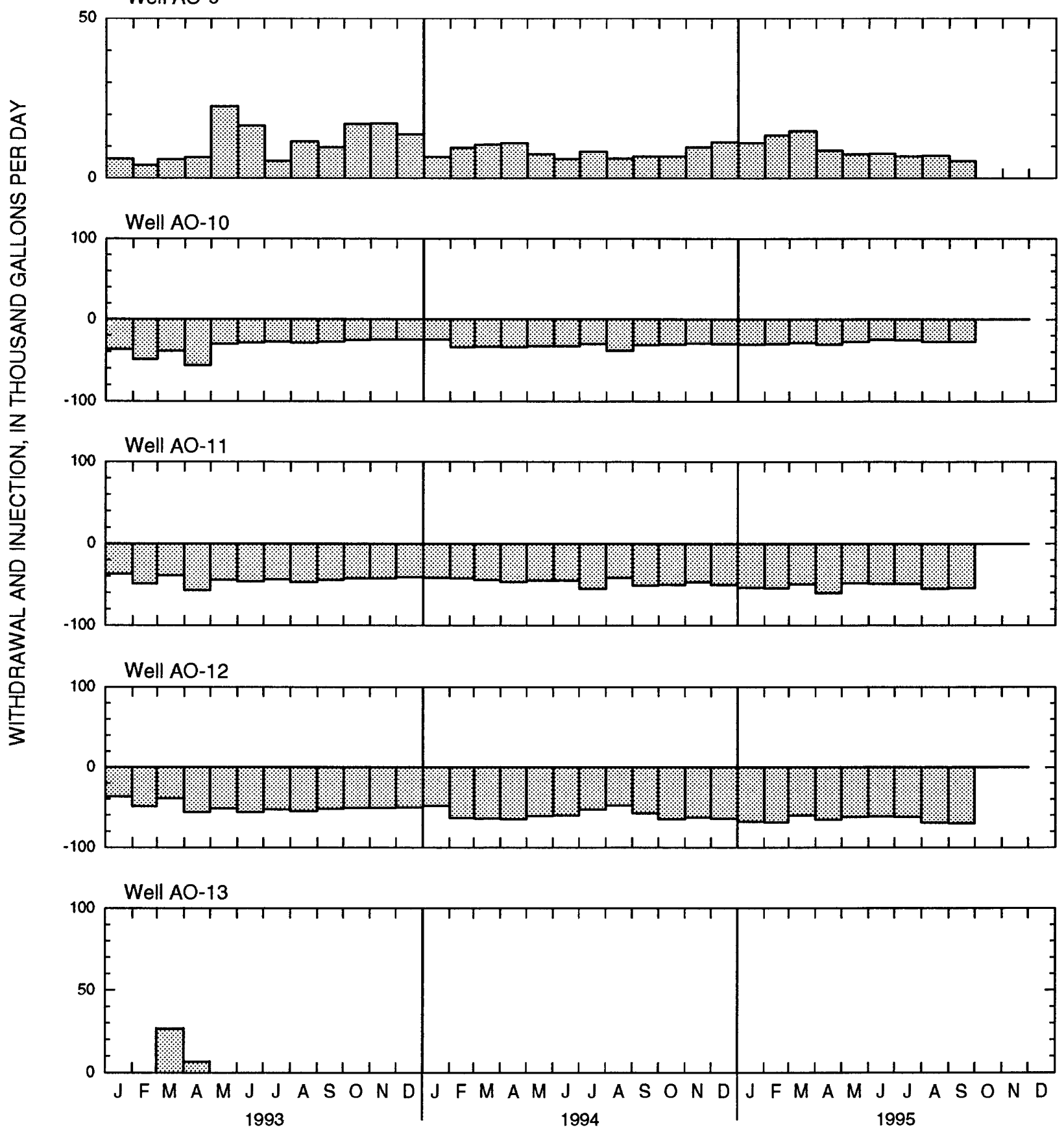

Figure B6 continued.--Monthly mean ground-water withdrawal and injection at wells AO-2 through AO-19 at Air Operations, Diego Garcia, January 1993 through September 1995. Injection is plotted as negative. 

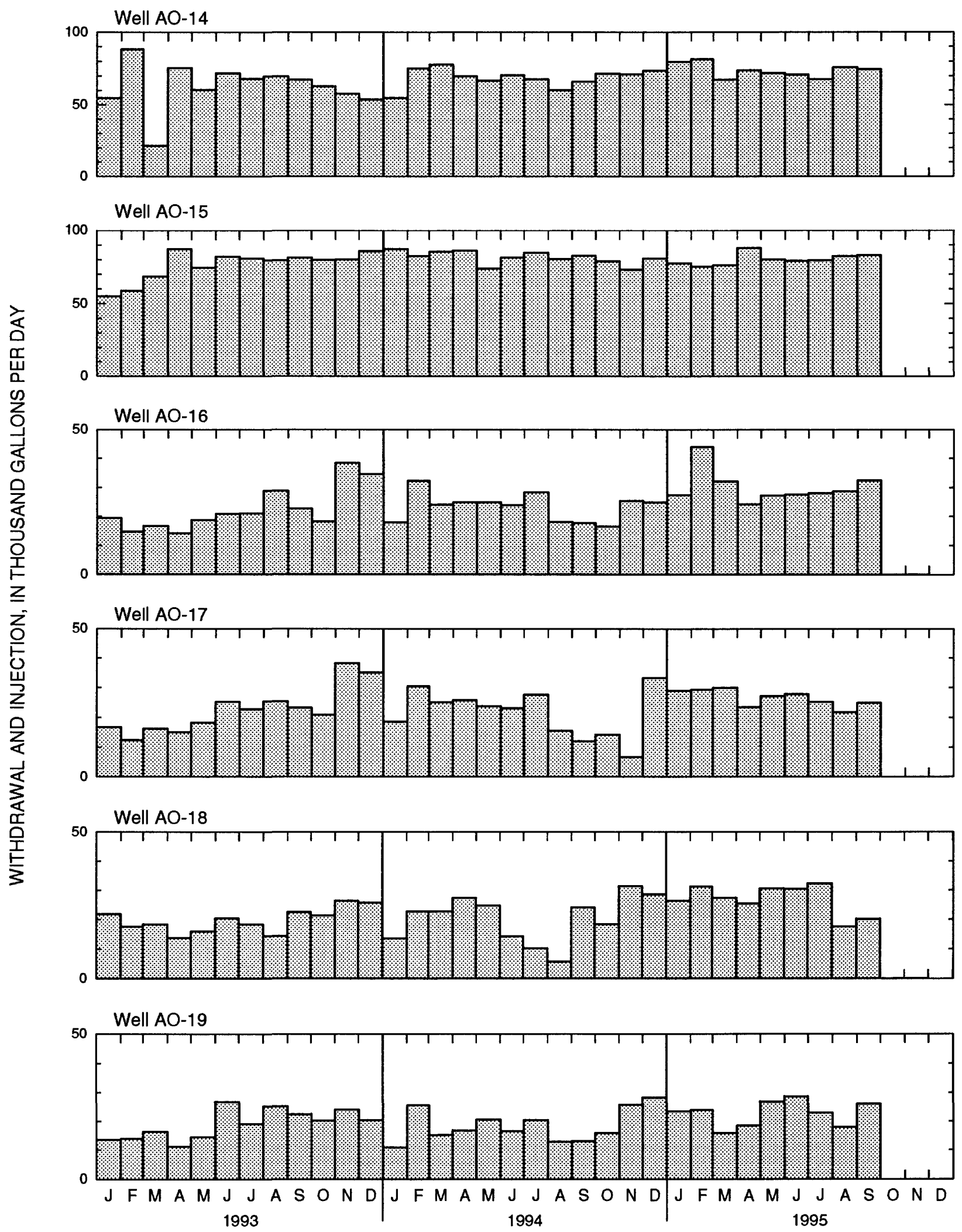

Figure B6 continued.--Monthly mean ground-water withdrawal and injection at wells AO-2 through AO-19 at Air Operations, Diego Garcia, January 1993 through September 1995. Injection is plotted as negative. 


\section{SECTION C}

\section{Graphs of chloride concentration of pumped water, January 1993 through September 1995}



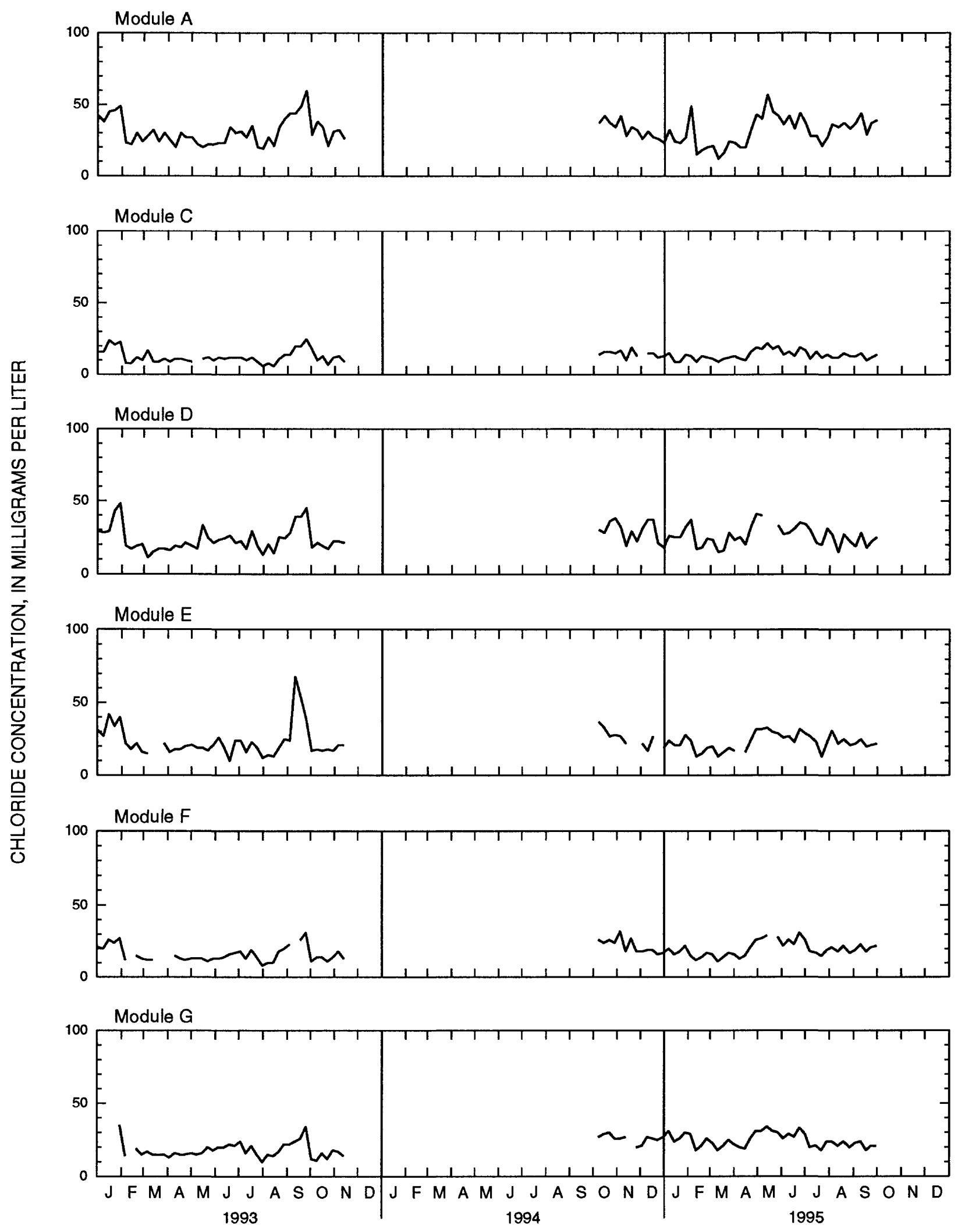

Figure C1. Chloride concentration of pumped water (sampled at weekly intervals) at Modules A through L at Cantonment, Diego Garcia, January 1993 through September 1995. Data not available for November 1993 through September 1994. 

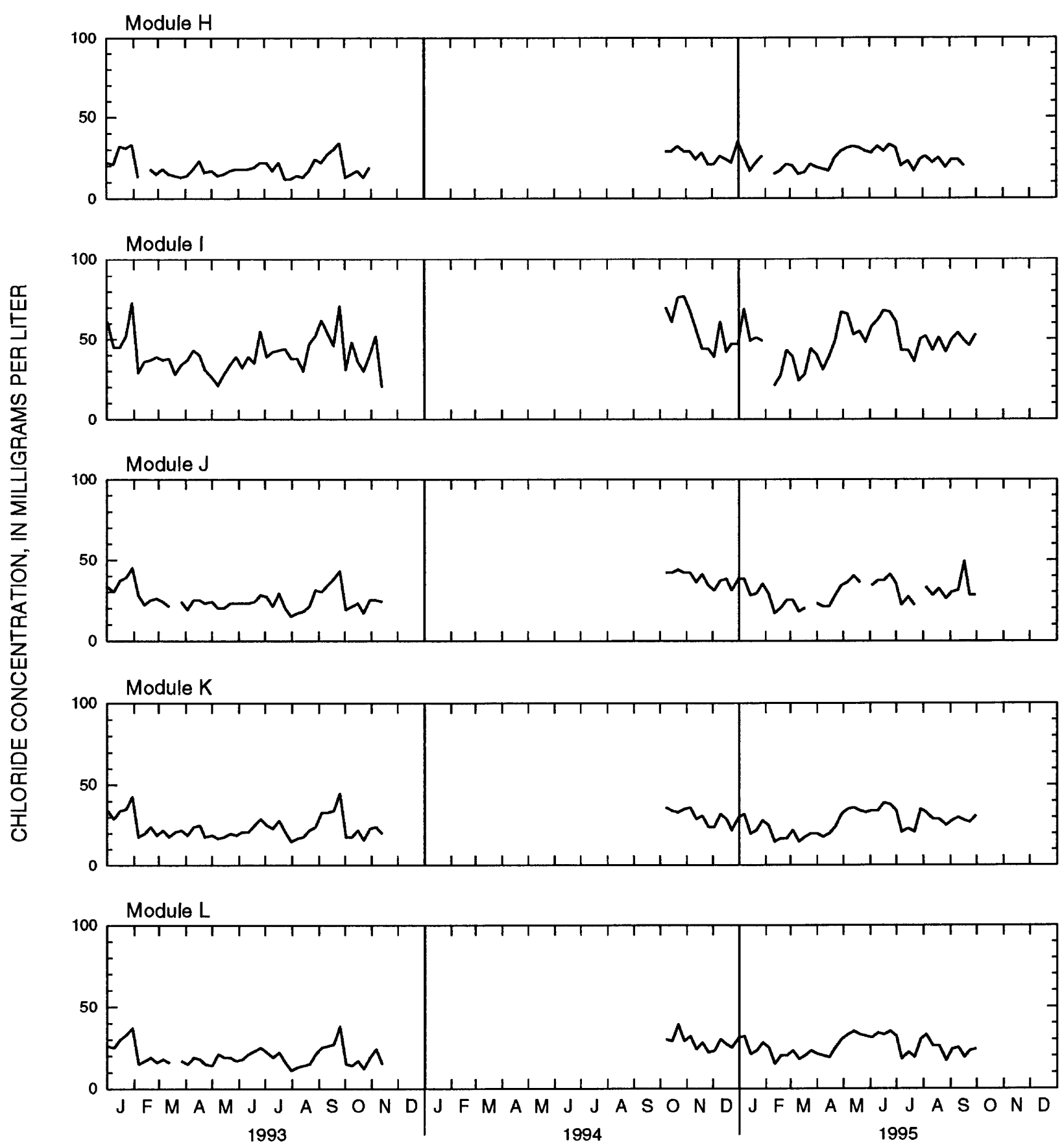

Figure $\mathrm{C} 1$ continued.--Chloride concentration of pumped water (sampled at weekly intervals) at Modules A through L at Cantonment, Diego Garcia, January 1993 through September 1995. Data not available for November 1993 through September 1994. 

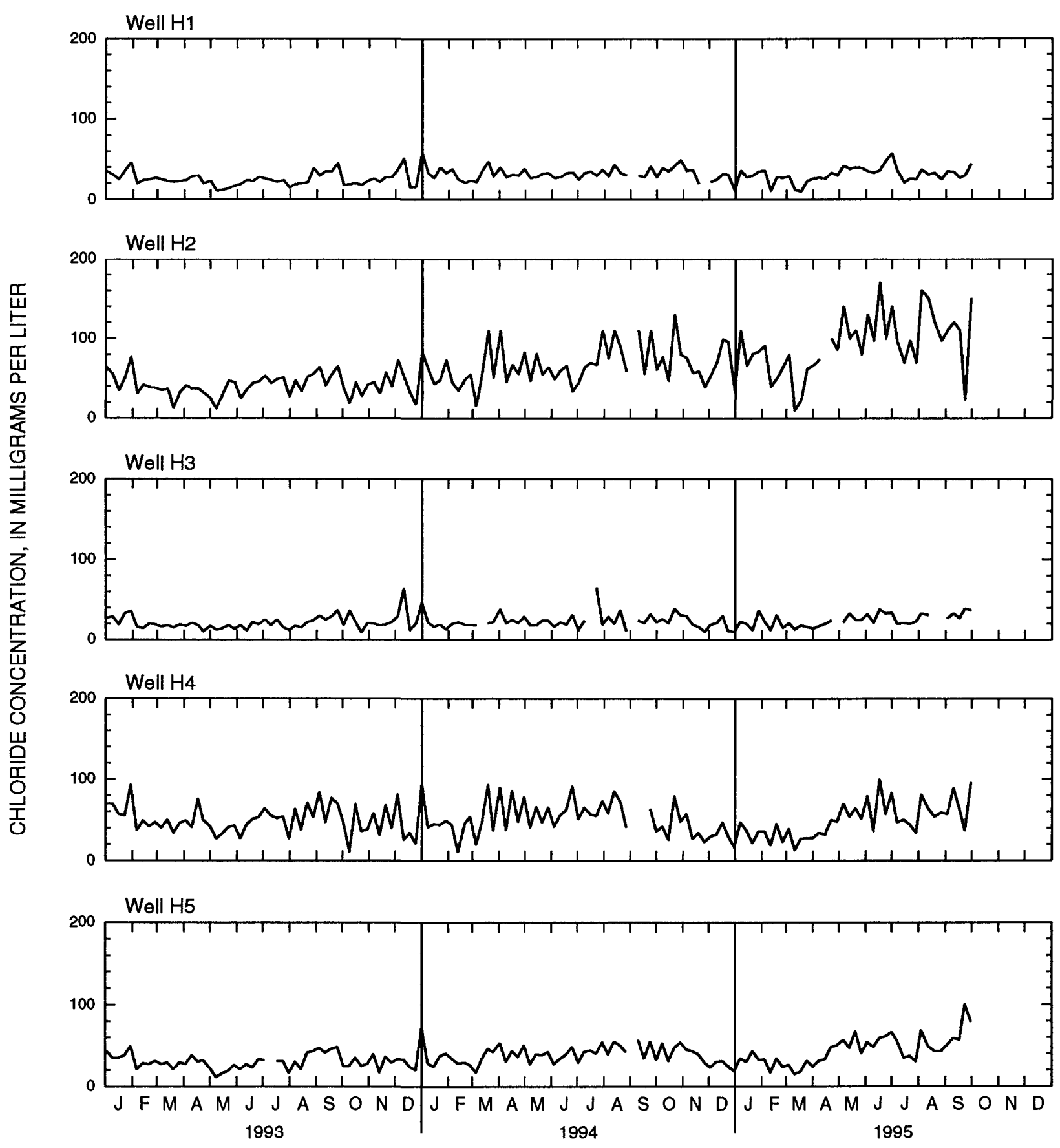

Figure C2. Chloride concentration of pumped water (sampled at weekly intervals) at wells $\mathrm{H} 1$ through $\mathrm{H} 7$ at Cantonment, Diego Garcia, January 1993 through September 1995. 

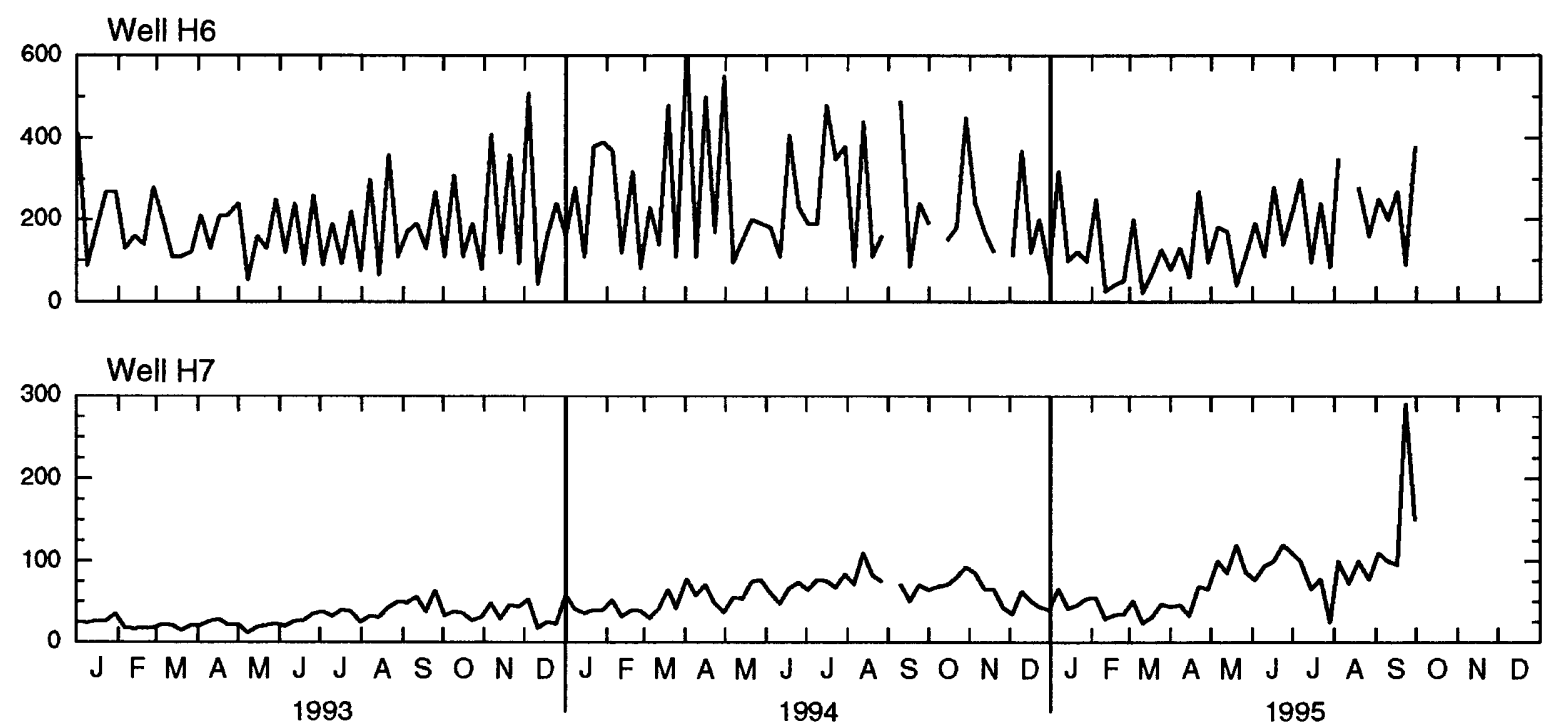

Figure $\mathrm{C} 2$ continued.--Chloride concentration of pumped water (sampled at weekly intervals) at wells H1 through H7 at Cantonment, Diego Garcia, January 1993 through September 1995. 


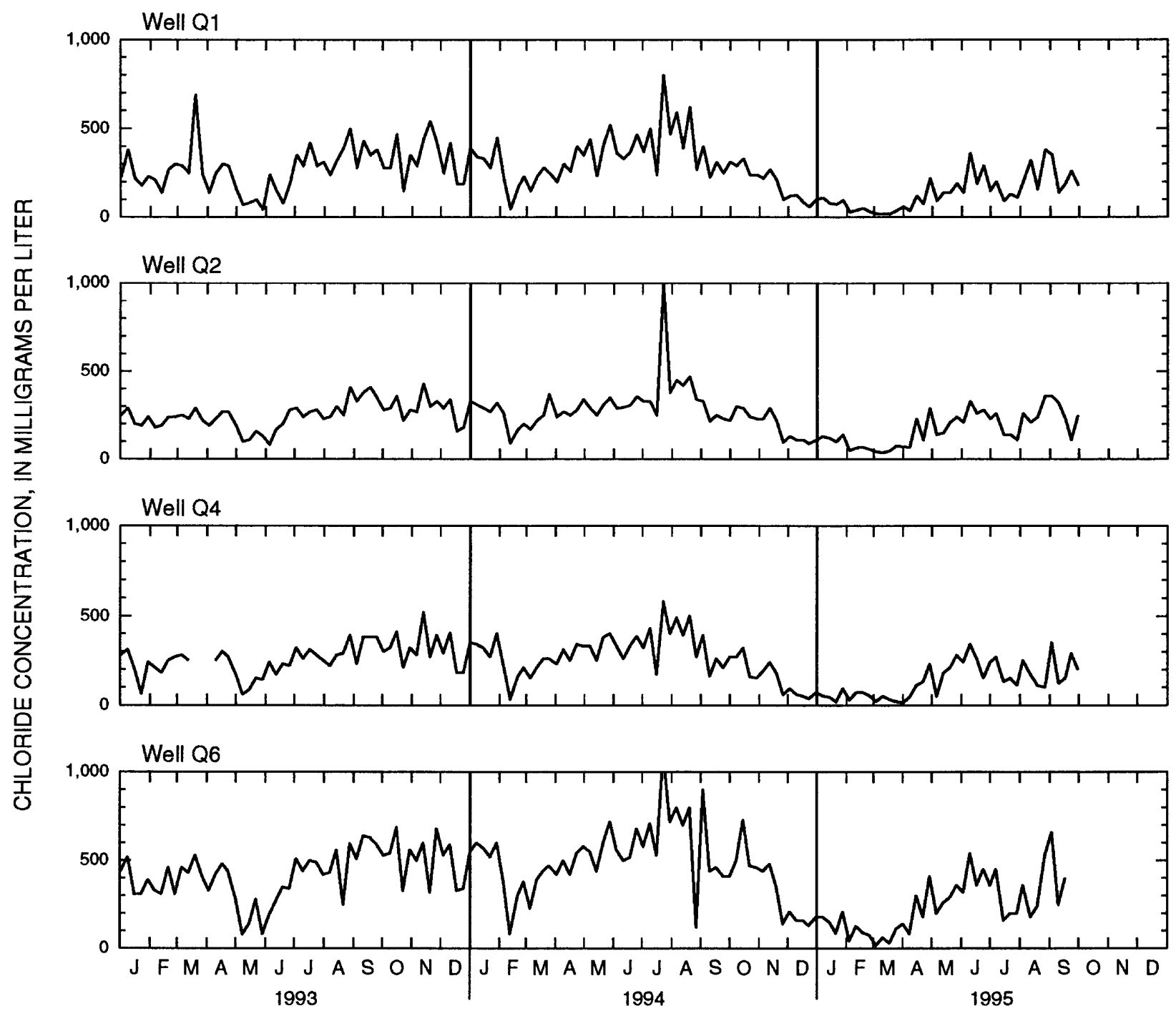

Figure C3. Chloride concentration of pumped water (sampled at weekly intervals) at wells Q1, Q2, Q4, and Q6 at Cantonment, Diego Garcia, January 1993 through September 1995. 
Well AO-2
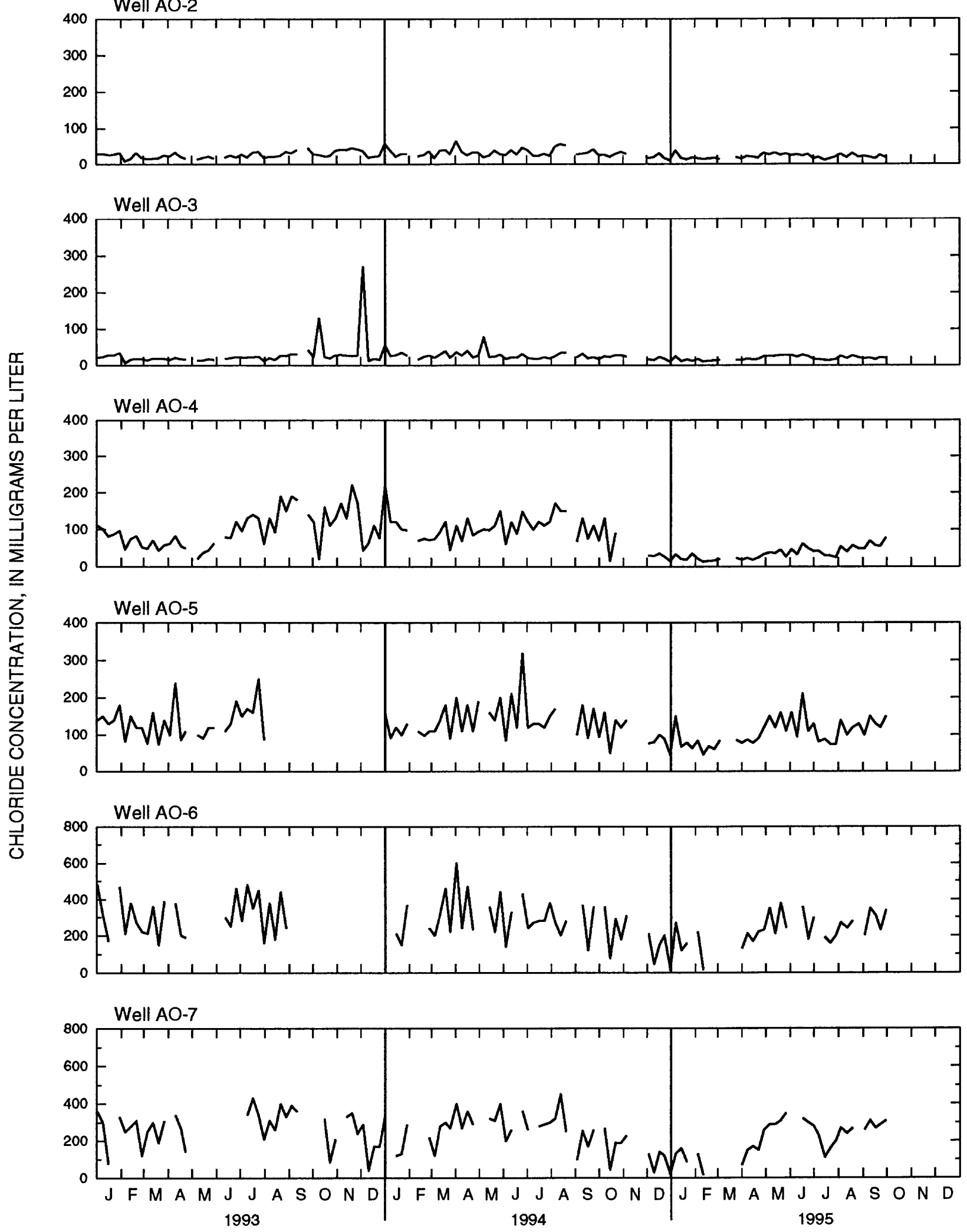

Figure C4. Chloride concentration of pumped water (sampled at weekly intervals) at wells AO-2 through AO-19 at Air Operations, Diego Garcia, January 1993 through September 1995. Water from well AO-13 has not been sampled since April 1993. 
Well $\mathrm{AO}-8$
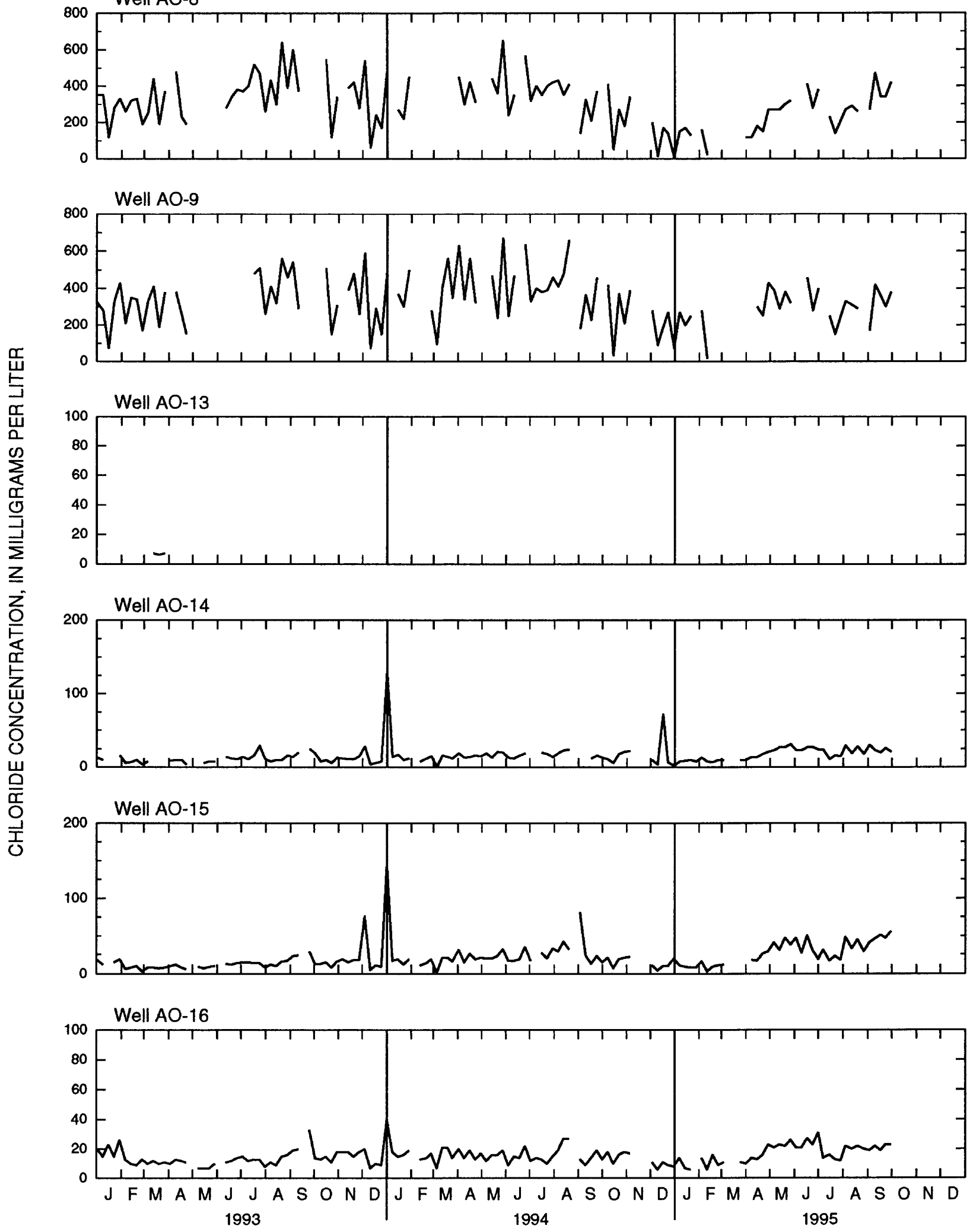

Figure C4 continued.--Chloride concentration of pumped water (sampled at weekly intervals) at wells AO-2 through AO-19 at Air Operations, Diego Garcia, January 1993 through September 1995. Water from well AO-13 has not been sampled since April 1993. 

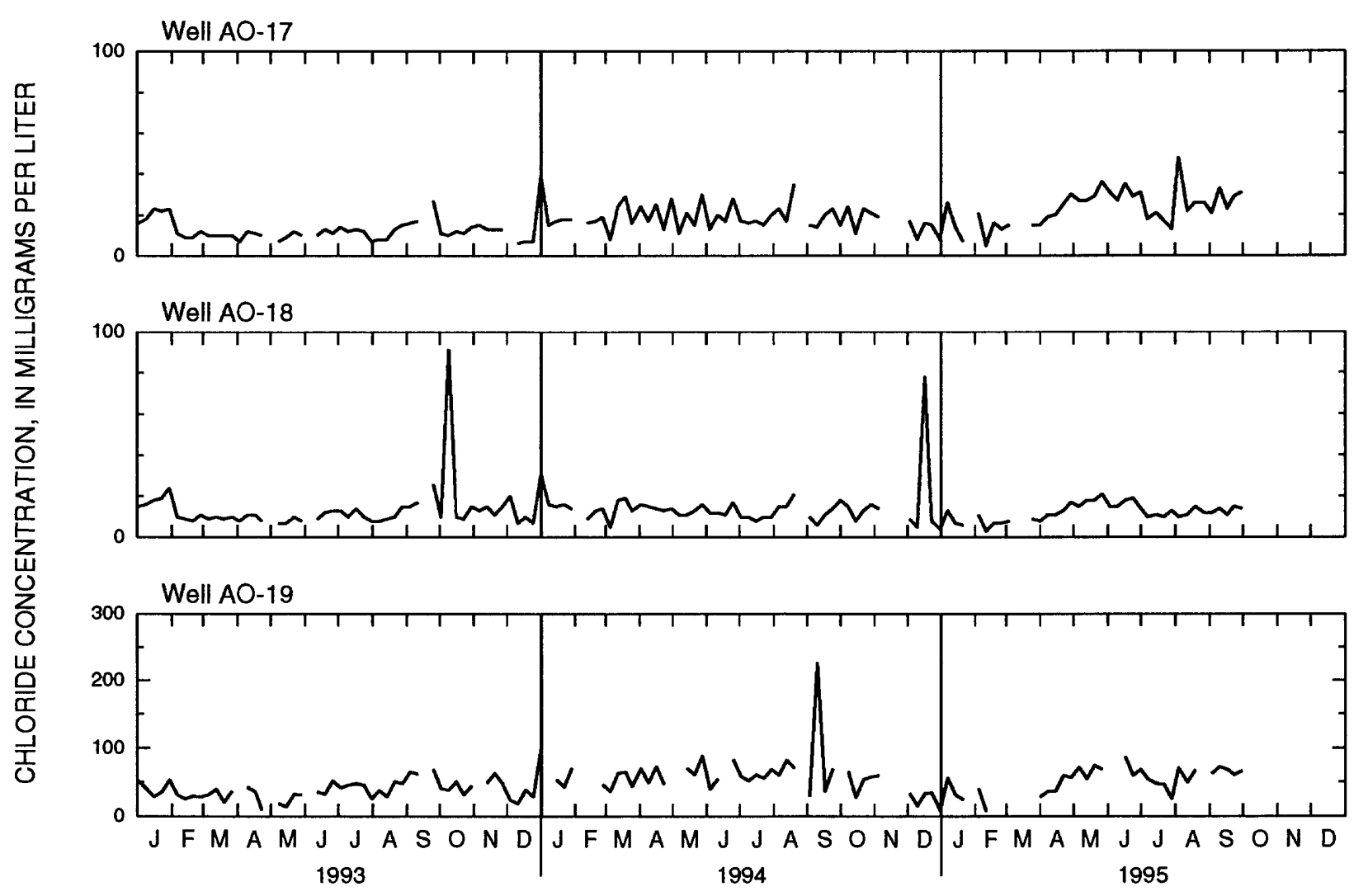

Figure C4 continued.--Chloride concentration of pumped water (sampled at weekly intervals) at wells AO-2 through AO-19 at Air Operations, Diego Garcia, January 1993 through September 1995. Water from well AO-13 has not been sampled since April 1993. 


\section{REFERENCES CITED}

Torikai, J.D., 1995, Status of ground-water resources at U.S. Navy Support Facility, Diego Garcia: Summary of hydrologic and climatic data through September 1993; U.S. Geological Survey Open-File Report 94-306, 51 p.

U.S. Environmental Protection Agency, 1991, Secondary maximum contaminant levels (section 143.3 of part 143, National secondary drinking water regulations): U.S. Code of Federal Regulations, Title 40, Parts 100 to 149, revised through July 1, 1991. 